
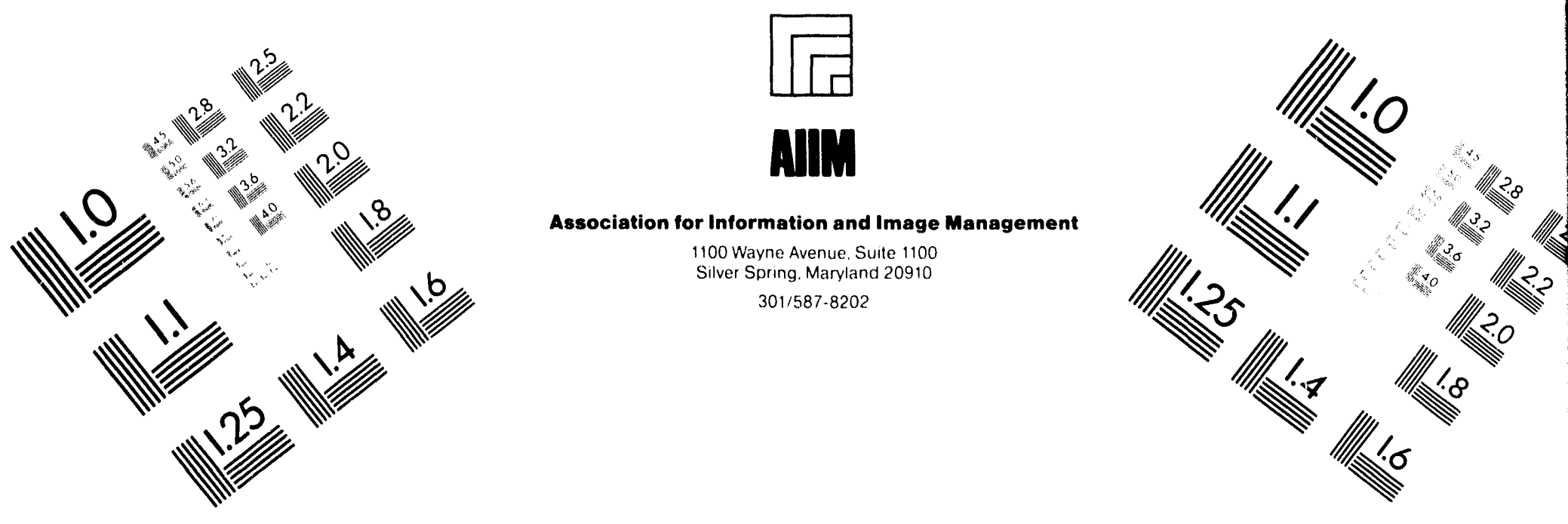

\title{
Centimeter
}

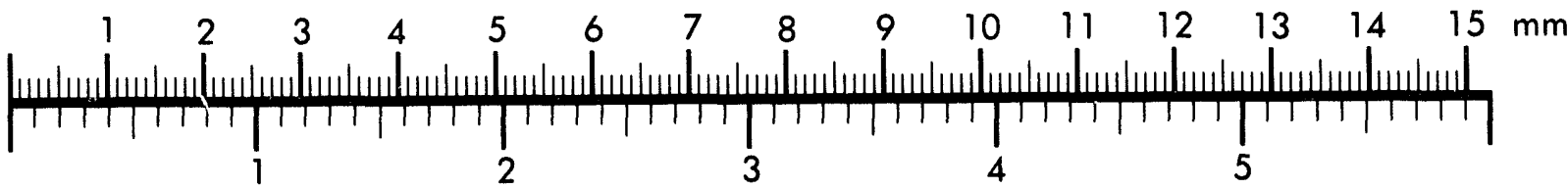
Inches
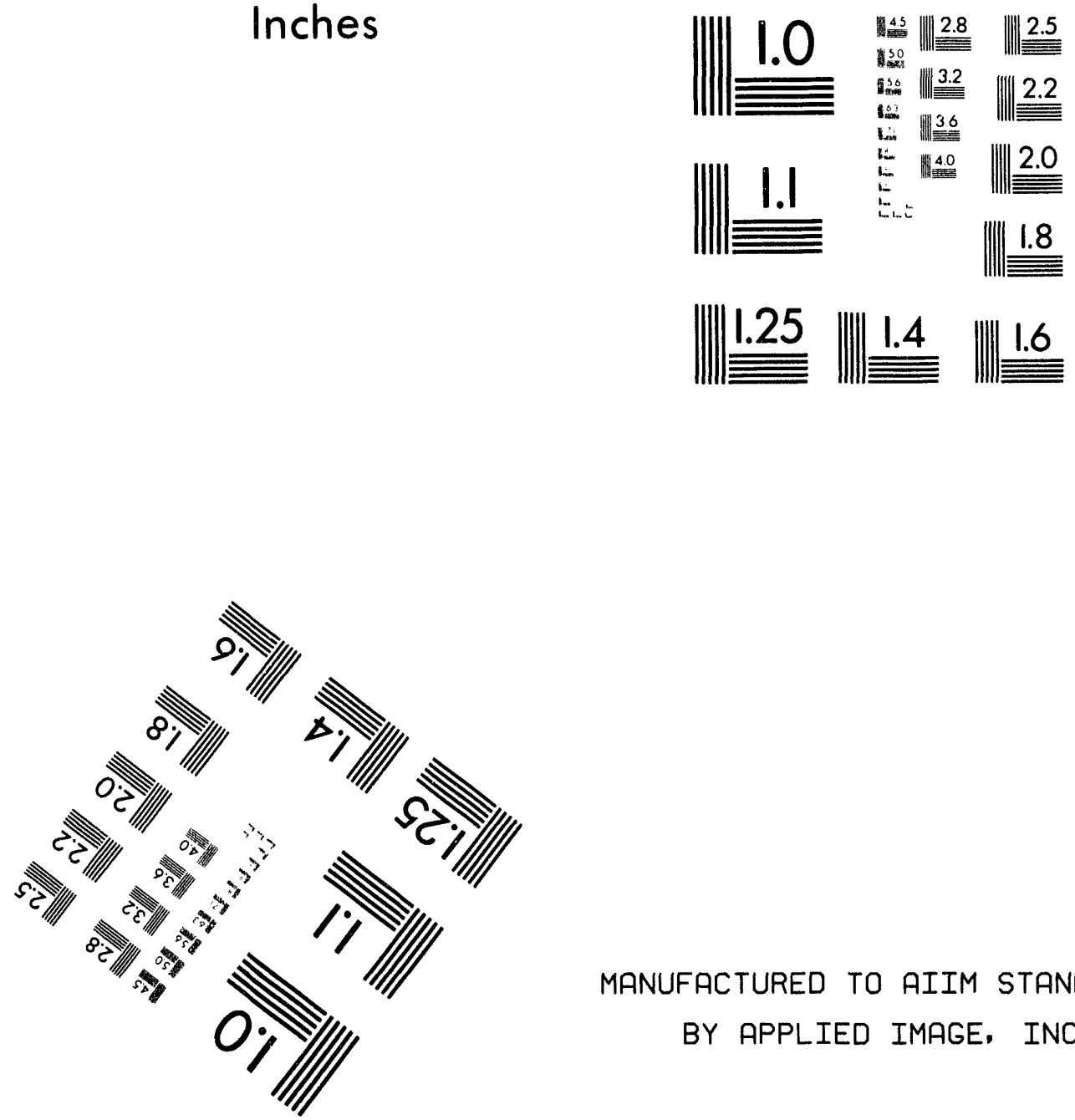

MANUFACTURED TO AIIM STANDARDS

BY APPLIED IMAGE, INC.

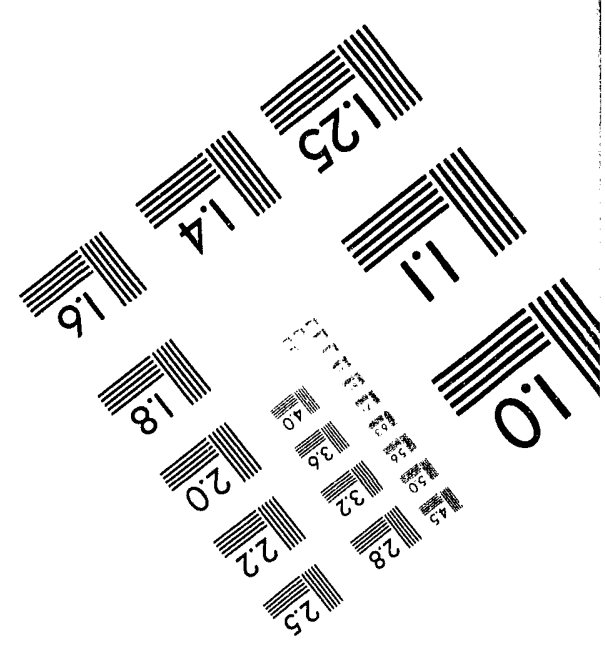



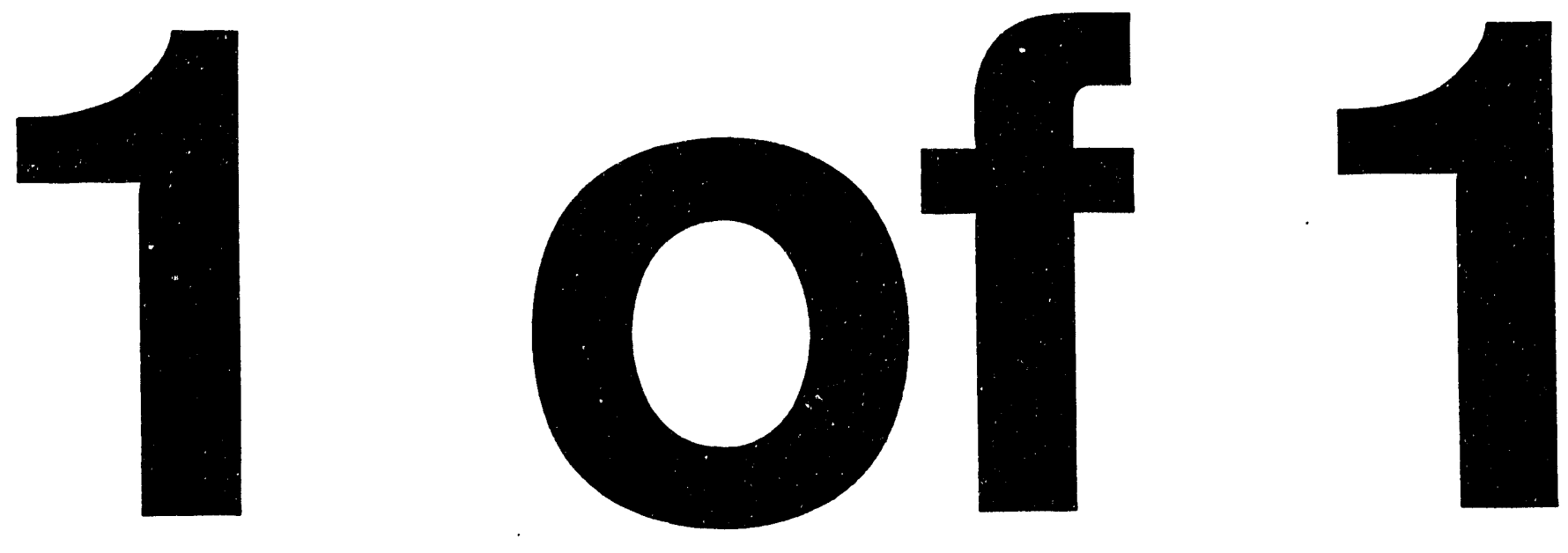


\section{Longitudinal Review of State-Level Accident Statistics for Carriers of Interstate Freight}

by C. Saricks and T. Kvitek

Center for Transportation Research, Energy Systems Division,

Argonne National Laboratory, 9700 South Cass Avenue, Argonne, Illinois 60439

March 1994

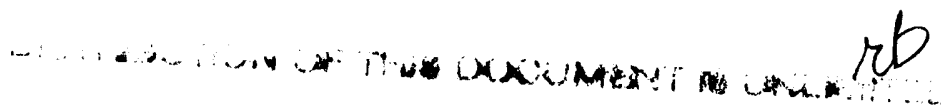

Work sponsored by United States Department of Energy, Assistant Secretary for Environmental Management 
This report is printed on recycled paper. 


\section{CONTENTS}

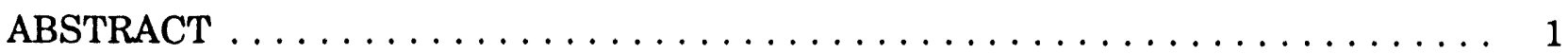

1 BACKGROUND AND OBJECTIVES $\ldots \ldots \ldots \ldots \ldots \ldots \ldots \ldots$

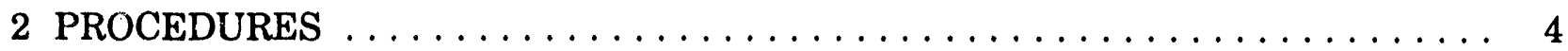

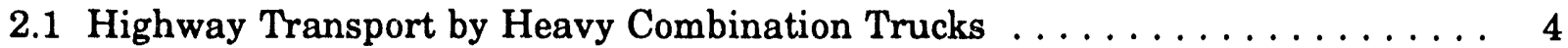

2.1 .1 Accident Data ........................... 5

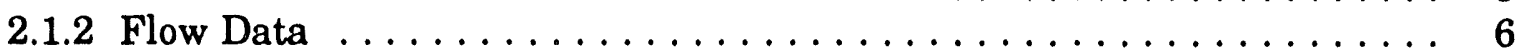

2.1.3 Empirical Verification and Subsequent Examination of Highway Rates . . . . . . . . . . . . . . . . . . 8

2.2 Railway Transport by Freight-Train Railcars $\ldots \ldots \ldots \ldots \ldots \ldots$

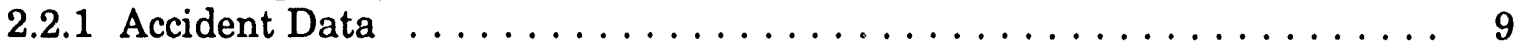

2.2 .2 Flow Data . . . . . . . . . . . . . . . . . . . . . . . . . 11

2.3 Waterway Transport by Barges and Other Marine Vessels . . . . . . . . . . . 12

2.3.1 Accident Data . . . . . . . . . . . . . . . . . . . . 13

2.3 .2 Flow Data . . . . . . . . . . . . . . . . . . . . 13

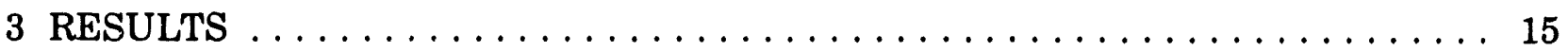

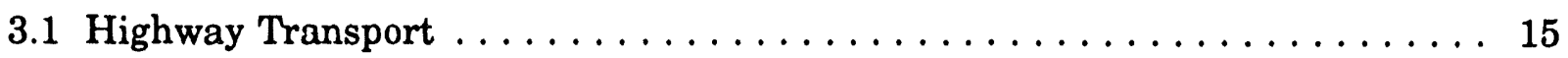

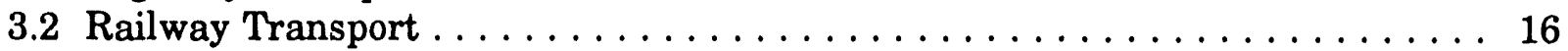

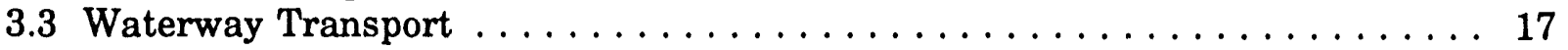

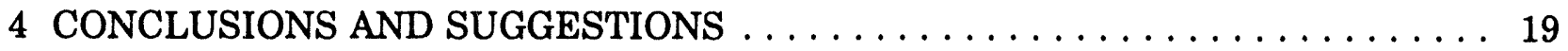

4.1 Highway Transport . . . . . . . . . . . . . . . . . . . . . . . 19

4.2 Railway Transport . . . . . . . . . . . . . . . . . . . . . . 19

4.3 Waterway Transport $\ldots \ldots \ldots \ldots \ldots \ldots \ldots \ldots \ldots \ldots$



APPENDIX: Accident Statistics and Rate Tables $\ldots \ldots \ldots \ldots \ldots \ldots \ldots$

\section{TABLES}

1 Filtered Accident Statistics for Interstate-Registered Heavy

Combination Trucks, for Six Representative States, 1991 . . . . . . . . . . . . . . 10

2 Highest One-Year Excursions from Three-Year Mean in Truck

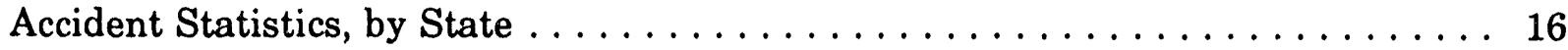

3 Highest Excursions from the Four-Year Mean in Waterway Accident and Casualty Statistics ........................... 18 


\section{TABLES (Cont.)}

A.1 Reportable Highway Combination-Truck Accidents, Fatalities, and Estimated Flows, by State and by Road Type, 1986

A.2 Reportable Highway Combination-Truck Accidents, Fatalities, and

Estimated Flows, by State and by Road Type, 1987

A.3 Reportable Highway Combination-Truck Accidents, Fatalities, and Estimated Flows, by State and by Road Type, 1988 . . . . . . . . . . . . 29

A.4 Highway Combination-Truck Accident, Fatality, and Injury Rates

Based on Reportable Interstate-Carrier Accidents, Reported

Fatalities and Injuries, and Estimated Flows, 1986-1988

A.5a Total and Mainline-Only, Reportable Railroad-Freight-Car Accidents

on Carrier-Owned Track and Estimated Car-Kilometers

for 1986,1987 , and 1988

A.5b Railroad-Freight-Car Accident Rates, by State, for 1986, 1987, 1988,

and 1985-1988 Combined

A.6 Freight-Vessel Accident and Casualty-Involvement Rates

on the Domestic Waterways of the United States, Including

Coastwise Shipping, for 1985

A.7 Freight-Vessel Accident and Casualty-Involvement Rates on the Domestic Waterways of the United States, Including Coastwise Shipping, for 1986

A.8 Freight-Vessel Accident and Casualty-Involvement Rates on the Domestic Waterways of the United States, Including Coastwise Shipping, for 1987

A.9 Freight-Vessel Accident and Casualty-Involvement Rates on the Domestic Waterways of the United States, Including Coastwise Shipping, for 1988

A.10 Freight-Vessel Accident and Casualty-Involvemen $\imath$ Rates on the Domestic Waterways of the United States, Including Coastwise Shipping, for 1985-1988 


\title{
LONGITUDINAL REVIEW OF STATE-LEVEL ACCIDENT STATISTICS FOR CARRIERS OF INTERSTATE FREIGHT
}

by

\author{
C. Saricks and T. Kvitek
}

\begin{abstract}
State-level accident rates by mode of freight transport have been developed and refined for application to the U.S. Department of Energy's (DOE's) environmental mitigation program, which may involve largequantity shipments of hazardous and mixed wastes from DOE facilities. These rates reflect multiyear data for interstate-registered highway carriers, American Association of Railroads member carriers, and coastal and internal waterway barge traffic. Adjustments have been made to account for the share of highway combination-truck traffic actually attributable to interstate-registered carriers and for duplicate or otherwise inaccurate entries in the public-use accident data files used. State-to-state variation in rates is discussed, as is the stability of rates over time. Computed highway rates have been verified with actual carriers of high-and low-level nuclear materials, and the most recent truck accident data have been used, to ensure that the results are of the correct order of magnitude. Study conclusions suggest that DOE use the computed rates for the three modes until (1) improved estimation techniques for highway combination-truck miles by state become available, (2) continued evolution of the railroad industry significantly increases the consolidation of interstate rail traffic onto fewer high-capacity trunk lines, or (3) a large-scale off-site waste shipment campaign is imminent.
\end{abstract}

\section{BACKGROUND AND OBJECTIVES}

Carriers of freight, regardless of commodity or mode of carriage, are subject to the risk of accidents in which cargo may be damaged and people may be killed or injured. The Center for Transportation Research of Argonne National Laboratory (ANL) has developeil a set of state- and waterway-specific "risk factors" aimed at increasing the understanding of accident risk involved in the transport of hazardous waste by authorized interstate carriers. The risk factors, which include accident involvements and accident-related fatalities and injuries, have been expressed as rates per unit-shipment distance.

This effort builds on work originally performed in support of the U.S. Department of Energy's (DOE's) development of a risk-analysis program for the shipment of spent 
commercial nuclear-reactor fuel under the Nuclear Waste Policy Act of 1986. That effort was broadened to include shipments of mixed and hazardous wastes that could be anticipated under DOE's site environmental mitigation program.

The calculated accident rates have been charted by transportation mode, within states or waterways; for highway transport by heavy combination trucks, rates have been charted by highway administrative class as well. An earlier set of risk-factor rates was included as risk-measurement units in the 1989 publication, Data Base of Accident and Agricultural Statistics for Transportation Risk Assessment (Saricks et al. 1989). That report cited several shortcomings in the method selected to compute the risk factors for transportation; chief among these shortcomings was the fact that the method's use of a single year's data (in this case, for 1985 or 1986) would fail to depict ongoing or newly emerging trends at the state level that use of consecutive, multiyear data could reveal; therefore, the method would also fail to indicate whether or not the individual risk factors were changing over time.

The authors of this report have five objectives:

1. To update the accident-risk-factor database with 1987 and 1988 data.

2. To increase the relevance and, ideally, the precision of the accident statistics applied as risk factors, by applying the best currently available information concerning only those carrier types of interest to the spent-fuel-shipping campaign, namely highway contract carriers that are interstate-registered, railroads that are members of the Association of American Railroads, and interstate barge lines.

3. To examine a through-time (longitudinal) series of accident data (minimum of three years) for each carrier type, in order to identify any indication of favorable or adverse responses to recent developments, such as the return to a $65-\mathrm{mph}$ speed limit on rural freeways, the compromise of some safety practices (as shown by the failure of combination trucks to pass state-administered, roadside safety checks), and the continuing consolidation of railroad traffic on more densely used lines.

4. To conduct statistical tests of annual values of rates for each transportation mode, by state.

5. To attempt to verify or empirically confirm the risk estimates for highway transport (which, of the three modes considered, relies on the most questionable public-use databases), through contact with individual carriers and examination of subsequent-year (i.e., 1991) accident and flow data for heavy combination trucks, to see if 1986-88 trends are continuing. 
The following section describes how the authors went about preparing revised rates and discusses the follow-up effort for preparing highway risk estimates. Section 3 presents and interprets findings by transportation mode, with respect to trends observed and statistical analyses performed. Section 4 discusses conclusions in light of those findings and identifies areas of further productive research. 


\section{PROCEDURES}

The procedures used to develop individual-year and through-time series of accident, fatality, and injury rates, by transportation mode and by state, were fundamentally identical to the procedures documented by Saricks et al. (1989); however, some modifications were made in order to provide more precise estimates. The approach for each transportation mode is described below.

\subsection{HIGHWAY TRANSPORT BY HEAVY COMBINATION TRUCKS}

Combination trucks are rigs composed of a separable tractor unit containing the engine/propulsion plant and one to three freight trailers connected to each other and to the tractor. These rigs generally weigh at least 26,000 pounds empty and up to 80,000 pounds fully laden, and each tractor-trailer combination generally has five or more axles. Just as the railroad freight car is the standard unit of haulage by rail, the heavy combination truck is the standard unit of haulage by highway. For this reason, we selected the full range of reported accidents of interstate-registered carriers as the appropriate basis of estimation for risk involved in transportation of spent fuel by highway.

We hypothesize that it is appropriate to use the universe of all interstate-registered heavy-truck movements as the basis of accident-involvement-rate computation because "trucks don't know their cargo." This is certainly valid to a point, and it implies a generally conservative approach. However, the argument is also tenable that, in the case of routecontrolled hazardous materials shipments, both shipper and carrier have a higher-thanaverage awareness of transport risk and prepare the cargoes and drivers for such shipments accordingly. This preparation should have a twofold effect of dramatically reducing component/equipment failure and mitigating the "human error" contribution to accident causation, leaving most remaining accident-precipitating events in the category of random occurrences largely unavoidable by the truck driver (such events collectively represent between 10 and $20 \%$ of total accident causation, on the basis of reported causative factors in the database). Thus, while risk for the backhaul or "deadhead" components of these shipments may assume the industry average, risk should be lower than average for the loaded miles.

Although it may be assumed that trucks carrying spent fuel will be subject to greater-than-average safety precautions, our analysis is conservative in that neither the type of cargo nor the lading status of the truck (i.e., loaded or empty) is a factor, and additional safety precautions are disregarded in the study. Risk involved in highway transportation is defined as the number of accident involvements ${ }^{1}$ of heavy combination trucks in a given year per unit of travel by these trucks in that same year. (If travel units were reported or

1 An accident is a truck-unit multiplier; for example, the collision of two trucks in a single accident represents two accident involvements. 
estimated in miles, they were converted to kilometers for consistency with the risk factors already embedded in hazardous waste calculations.) Therefore, the rate is a fractional value, with accident-involvement count as the numerator of the fraction and vehicular activity (total travel distance) as its denominator. For example, if there were 36,000 accident involvements among heavy combination trucks in 1986, and these trucks traveled 120 billion kilometers in that year, the risk would be

$$
\frac{3 \text { road accident involvements }}{10^{7} \text { shipment kilometers }} .
$$

Both loaded- and unloaded-truck travel is included in the denominator.

It was further determined that this unit should be broken down within a given state by road type according to the Federal-Aid Administration Classification System, which is the basis of federal formulas for funding road maintenance and improvement under the Federal-Aid Highway Act. This classification system is as follows: ${ }^{2}$

- Federal-Aid Interstate (FAI) highway system (urban and rural combined),

- Federal-Aid Primary (FAP) highway system, and

- Federal-Aid Secondary (FAS) (rural) highway systems.

The FAI is further divided into urbanized areas (FAI-U) and rural areas (FAI-R). Such a breakdown not only enhances estimation of within-state (between-classes) variance, to complement the depiction of between-states (nonstratified) variance, but also introduces into the database implicit qualities that can lead to higher or lower risk, such as differences among the systems with respect to average roadway standards and permitted extremes in road geometries.

State-level data for interstate-registered trucks (which consist of total counts of accident involvements by road type, sorted by state code) were processed to generate the numerators of the risk rates. The procedure for generating the denominator was less straightforward but aimed for equal reliability. This procedure is described in Section 2.1.2.

\subsubsection{Accident Data}

The primary source of combination-truck-accident data, with associated fatalities and injuries, is the 50-T Master File of Accidents of Motor Carriers of Property, compiled annually from carrier-submitted reports by the Office of Motor Carriers (OMC), formerly the Bureau of Motor Carrier Statistics (BMCS), of the U.S. Department of Transportation (DOT). The

2 Under the Intermodal Surface Transportation Efficiency Act of 1991, the "primary" and "secondary" classifications will be eliminated and combined into a single "National Highway System." 
50-T file is the only comprehensive, central source of accessed data for public use: it covers accident involvements of heavy combination trucks owned and operated by interstate-regulated carriers, by year and for all states. All but a few of the accidents recorded in this file each year involve some configuration ("bobtail" to "turnpike triple") of heavy combination truck, and only records involving such configurations were selected. Reporting requirements in the past have stipulated that carriers must report any accident in which damage to property of $\$ 2,000$ or more was recorded, or in which a fatality or injury occurred (reporting of other accidents was at the carriers' discretion). Subsequently, the reporting threshold was raised to $\$ 4,200$ in $1986, \$ 4,400$ in 1987 , and $\$ 4,900$ in 1988 , with the fatality and injury criteria being retained.

Using the Statistical Analysis System ${ }^{\circledR}$ (SAS), we generated a state-by-state listing of the salient components of each of the accident-involvement records for heavy combination trucks in the OMC 50-T master files for 1986, 1987, and 1988. From this information, we manually assigned the accident location provided on each record to the relevant administrative category (FAI-U, FAI-R, FAP, FAS, or none of the above). This in turn necessitated state-by-state transcription of the FAP system overlay from a national inap of that system provided by the regional office of the Federal Highway Administration (FHWA). Because carrier reporting occasionally results in duplication of entries for fatalities and/or injuries in a given accident, we scrupulously checked SAS records to eliminate such double-counting.

Although the method detailed above is rather cumbersome, we determined that it was at least 50\% more accurate (assuming that the 50-T records are complete and authentic) than the method used in a pilot study for this task, in which accident records were tabulated according to the road-identifier preface of the coded location. Moreover, our method enabled efficient "cleanup" of misassigned or miscoded records, a step that proved to be especially important when dealing with years for which a very large number of reportable accidents appeared in the data. With the annual miscoding rate being about constant, the total number of incorrect records was higher in such years, and propagation of error would have been greater.

\subsubsection{Flow Data}

To construct a denominator for the estimate of road accident/fatality risk per shipment-kilometer, it was necessary to develop estimates of total kilometers (converted from miles) of combination-truck travel, by state, per unit of time. The following factors also needed to be considered: (1) a proportion of truck travel is deadhead mileage, in which no actual shipment is involved; and (2) a truck's accident risk is largely independent of its cargo. Therefore, for both highway and rail activity, all relevant movements, loaded or empty, are included in the denominator.

In its annual publication Highway Statistics, the FHWA reproduces a series of tables that present the results of data analyses performed by using fuel sales data reported by states, vehicle counts by type at official 24-hour counting stations across the country, and data from such studies as the Truck Inventory and Use Survey (U.S. Bureau of the Census 
1982) regarding vehicular usage patterns and fuel economy. More detailed versions of these tables, in spreadsheet format, are released to the public on floppy disks by the FHWA's Office of Highway Information Management. The detailed tables permit estimation of vehicle-miles of travel (VMT) by state, by vehicle type, and by urban and rural roadway classification. However, the numerators (accident counts) for each rate include only data from accidents reported by interstate-registered carriers; therefore, it was necessary to adjust the denominator (travel distance) in each case to approximate the state-level travel accounted for only by heavy combination trucks involved in interstate movements. This adjustment was made possible by estimating shares of heavy-truck travel accounted for by operators who traveled exclusively to predominantly intrastate and those who traveled primarily interstate, as reported in the 1987 Truck Inventory and Use Survey (TIUS).

According to TIUS, over-the-road, diesel-powered trucks with gross weight in excess of 33,000 pounds (virtually ali of which are heavy combination rigs) nationally account for about $13 \%$ of all truck-miles. Of these trucks, some 35\% (accounting for over 28 billion VMT annually) accumulate more than $25 \%$ of total miles on roads outside incir "home" state of registry. We selected the travel share of this subset, approximately $53 \%$ of total travel by heavy combination trucks, as representing the accrual attributable to interstate-registered carriers. Thus, we applied an initial multiplier (deflator) of 0.53 to FHWA's estimate of total combination-truck miles for each state. An additional adjustment was then made to reflect the differences in VMT participation of interstate carriers by administrative class. For example, we deflated rural interstate VMT by combination-trucks by only $30 \%$ (that is, interstate carriers account for $70 \%$ of the combination-truck VMT on rural interstate highways), but we deflated urban interstate VMT by at least $40 \%$ and federal-aid secondary VMT by $70 \%$, to echo the relatively greater use of these facilities by locally oriented, noninterstate trucks. Deflators are based on the nationwide share of reported accidents accounted for by each administrative class. Following adjustment, we renormalized the sum of each state's combination-truck VMT over all classes, including those classes not used in the spent-fuel transportation study (i.e., federal-aid urban and all nonfederal systems), to $53 \%$ of the original FHWA total. The resulting final shares for FAI-R, FAI-U, FAP, and FAS became the rate denominators.

Rates were computed for 1986,1987 , and 1988 individually and for the three years collectively. (See Tables A.1 through A.4 in the Appendix.) Data for the numerators (accident, fatality, and injury counts) were derived exclusively from the 50-T file of the OMC.

Remaining problems with the use of the FHWA flow data include missing information and possible bias in counting station-related data. In the current floppy-disk files, the combination-truck share of VMT for Oklahoma is given only for 1986, necessitating the use of the 1986 split for Oklahoma for all three years. Also, apparently there were some misplaced decimal points in New Mexico's truck-VMT shares for 1988 . In some cases, combination-truck shares based on counts at permanent counting stations of the Highway Performance Monitoring System (HPMS) reflect the expectation that a large number of trucks will be counted at that site, rather than a desire to establish a truly random surveillance location. However, until significantly better methods for estimating heavy-truck flows by 
state are generally available, the application of HPMS counts and state fuel-tax data used by the FHWA to prepare VMT estimates is probably the best available alternative. Nonetheless, the reliability of this approach should be checked and questioned periodically, especially as better data and techniques become available ( $\mathrm{Hu}$ et al. 1990).

An enhancement to the process of preparing the rates for combination trucks is that all components of the annual 50-T accident records except counting, checking, and quality assurance are now fully automated for each year. This permits faster updating and investigation of data already collected and creates the opportunity for more efficient computation of rates for additional years.

\subsubsection{Empirical Verification and Subsequent Examination of Highway Rates}

Because the application of available statistics for combination-truck travel is not as straightforward as that for freight-train railcars and barges, and because some of the information itself is not as reliable, we felt we needed additional verification of highway rates. In an effort to verify or at least increase the credibility of tive revised accident risk/probability rates for highway transport by heavy combination vehicles, we consulted two sources.

The first source was information obtained directly from the transportation-services divisions of four over-the-road carriers of high- and low-level nuclear materials; these carriers were:

1. Nuclear Assurance Corp., Georgia;

2. Tri-State Transportation (a subsidiary of TRISM, Inc.), Missouri;

3. McGil Special Services, Georgia; and

4. Hittman Transport, Pennsylvania.

Representatives of the transport service divisions listed above were all contacted by telephone; in each case, one of the authors spoke with either the director of transportation services (often a corporate vice-president in charge of specialized operations) or an officer of the division within the company that had been given responsibility for carrier operations. Each was asked the following question: is a range of one to five reportable accidents per 10 million $\left(10^{7}\right)$ total truck-miles consistent with, higher than, or lower than your firm's experience? Two of the four provided actual computed rates in this range, on the basis of experience in 1992 and 1993, while the other two indicated that their long-term experience fell precisely within this range, even when unladen miles were included (Anderson 1993; Cooney 1993; Shelton 1993; Kirby 1994). A conclusion reached from these discussions is that rate estimates reported in Table A.4 of this document, as applied to haulers of high- and lowlevel nuclear materials by tractor-trailer combination trucks, are in the correct order of magnitude. Perhaps, if consideration is limited to truck-miles involved with actual manifest movements, the estimates might even be slightly high. 
The second source was 1991 data from the DOT Office of Motor Carriers (a filtered, cleaned version of the 50-T file for calendar 1991), combined with data derived from the 1991 edition of the FHWA's Highway Statistics giving estimates of miles traveled by interstate-registered carriers driving heavy combination trucks. Six typical states in 1991 were examined (see Table 1) as the basis of a second assessment of whether the accident/fatality/injury rates given in Table A.4 were sufficiently conservative or would require upward revision. Again, the universe of cases was restricted to reportable accidents ard (estimated) kilometers of travel, by state, of heavy combination trucks operated by motor carriers of property registered with the Interstate Commerce Commission (ICC). DOE is likely to require both interstate registry and specialty-transport certification for any highway carrier with whom it contracts for transport of large-volume wastes, but our data do not permit specific identification of such carriers in both the accident and travel-activity database; thus, we examined the larger subset of all ICC-registered carriers. The selected states are "typical" for the purpose at hand in that a high proportion of heavy-combinationtruck shipments passing through them has both origin and destination beyond the state borders (i.e., they are important corridor states), yet a broad spectrum of truck shipments also originates or terminates within the state.

As the figures in Table 1 indicate, there has been little change, except primarily downward, from the Table A.4 rates for these states, even though reported accidents off of the interstate system in urban areas (but still occurring on the Federal-Aid system) are now included. These results also appear to reconfirm the Table A.4 rates as reasonable and in the correct order of magnitude.

\subsection{RAILWAY TRANSPORT BY FREIGHT-TRAIN RAILCARS}

As for highway transport, it was deemed appropriate for rail transport that we examine the types of railroad shipments involved in relocation of spent fuel. Spent-fuel casks will move over railroad routes in sections of one, two, three, or more railcars, up to and including unit (dedicated) trains. Therefore, although the propulsion medium for rail shipments is the locomotive, the conveyance (haulage) medium is the railcar, which has no independent powe: source and may bear the consequences of forces originating from elsewhere in the train.

\subsubsection{Accident Data}

The rail numerator, parallel to the numerator for the truck-accident unit-risk factor, is total, reportable railcar-accident involvements, by state, per unit of time. In this case, distinctions may be drawn from available data about the type of track on which an accident occurred (main, yard, siding, or industrial); however, similar partitioning according to track-speed class (an index of track physical condition) is very difficult, because this parameter is incomplete in accident records and does not appear at all in flow data. 
TABLE 1 Filtered Accident Statistics for Interstate-Registered Heavy Combination Trucks, for Six Representative States, $1991^{\mathrm{a}}$

\begin{tabular}{|c|c|c|c|c|c|c|c|c|c|}
\hline State & Total & $\begin{array}{l}\text { Inter- } \\
\text { State }\end{array}$ & $\begin{array}{c}\text { Other } \\
\text { F-A }\end{array}$ & Fatalities & Injuries & $\begin{array}{c}\mathrm{I} / \mathrm{R} \\
\text { HCTVM }^{\mathrm{c}}\end{array}$ & Acc. Rate & Fat. Rate ${ }^{d}$ & Inj. Rate ${ }^{d}$ \\
\hline Alabama & 533 & 224 & 309 & $\begin{array}{l}I^{e}=6 \\
\mathrm{OFA}^{\mathrm{e}}=51\end{array}$ & $\begin{array}{l}I=234 \\
O F A=286\end{array}$ & $\begin{array}{l}I=1364 \\
\text { OFA }=734\end{array}$ & $\begin{array}{l}I=1.64 \\
\mathrm{OFA}=4.21\end{array}$ & $\begin{array}{l}I=0.44^{f} \\
O F A=6.95\end{array}$ & $\begin{array}{l}I \quad=1.72 \\
O F A=3.90^{f}\end{array}$ \\
\hline Arizona & 298 & 239 & 59 & $\begin{array}{l}I=25 \\
\text { OFA }=10\end{array}$ & $\begin{array}{l}I=238 \\
\text { OFA }=65\end{array}$ & $\begin{array}{l}I=1148 \\
O F A=492\end{array}$ & $\begin{aligned} I & =2.08 \\
\text { OFA } & =1.20^{f}\end{aligned}$ & $\begin{aligned} I & =2.18 \\
O F A & =2.03^{f}\end{aligned}$ & $\begin{aligned} \mathrm{I} & =2.07 \\
\text { OFA } & =1.32^{\mathrm{f}}\end{aligned}$ \\
\hline Indiana & 963 & 514 & 449 & $\begin{array}{l}I=35 \\
\text { OFA }=44\end{array}$ & $\begin{array}{l}I \quad=409 \\
O F A=424\end{array}$ & $\begin{array}{l}I \quad=2722 \\
\text { OFA }=1281\end{array}$ & $\begin{array}{l}I \quad=1.89^{f} \\
O F A=3.51\end{array}$ & $\begin{aligned} I & =1.29^{f} \\
O F A & =3.43^{f}\end{aligned}$ & $\begin{array}{l}I=1.50^{f} \\
O F A=3.31\end{array}$ \\
\hline Kansas & 327 & 117 & 210 & $\begin{array}{l}I=4 \\
O F A=23\end{array}$ & $\begin{array}{l}I \quad=107 \\
\text { OFA }=189\end{array}$ & $\begin{array}{l}I=446 \\
O F A=403\end{array}$ & $\begin{array}{l}I=2.62 \\
\text { OFA }=5.21\end{array}$ & $\begin{aligned} I & =0.90^{\mathrm{f}} \\
O F A & =5.71^{\mathrm{f}}\end{aligned}$ & $\begin{aligned} I & =2.40 \\
O F A & =4.69^{g}\end{aligned}$ \\
\hline Virginia & 534 & 311 & 223 & $\begin{array}{l}I \quad=23 \\
O F A=23\end{array}$ & $\begin{array}{l}I=299 \\
\text { OFA }=232\end{array}$ & $\begin{array}{l}I=1284 \\
O F A=604\end{array}$ & $\begin{aligned} I & =2.42 \\
G F A & =3.69^{f}\end{aligned}$ & $\begin{array}{l}\mathrm{I}=1.79^{\mathrm{f}} \\
\text { OFA }=3.81^{\mathrm{f}}\end{array}$ & $\begin{aligned} \mathrm{I} & =2.34 \\
\mathrm{OFA} & =3.84^{\mathrm{f}}\end{aligned}$ \\
\hline Washington & 255 & 162 & 93 & $\begin{array}{l}I \quad=12 \\
\text { OFA }=10\end{array}$ & $\begin{array}{l}I=132 \\
\text { OFA }=74\end{array}$ & $\begin{array}{l}I=755 \\
O F A=618\end{array}$ & $\begin{aligned} I & =2.15 \\
O F A & =1.51^{f}\end{aligned}$ & $\begin{array}{l}I=1.59^{\mathrm{g}} \\
\text { OFA }=1.62\end{array}$ & $\begin{aligned} I & =1.75 \\
\text { OFA } & =1.20^{f}\end{aligned}$ \\
\hline
\end{tabular}

a Counts in columns 2-4 include duplicate entries in the 50-T file that are obviously multivehicle involvements reported by two or more carriers but injuries or fatalities arising from these accidents are not double-counted. Entries for off-road locations [e.g., parking lot, truck stop, PU/D site] are excluded, as are local street locations that would not be traveled by a DOE hazardous materials shipment. All locations on the designated Federal-Aid system identified as of 1991 are included, whether or not the route would permit avoidance of densely populated areas.

b F-A = All other designated Federal-Aid system routes; candidates for inclusion in National Highway System are defined pursuant to Intermodal Surface Transportation Efficiency Act of 1991.

c IR HCTVM = Millions of estimated travel-kilometers (laden and unladen) in the state by interstate-registered, heavy combination trucks.

d Acc. Rate, Fat. Rate, Inj. Rate $=$ Calculated accident-involvement rate per $10^{7}$ truck-kilometers, fatality rate per $10^{8}$ truck-kilometers, and injury rate per $10^{7}$ truck kilometers, respectively, by interstate-registered, heavy combination carriers over Interstate and other Federal-Aid highways.

e I signifies Interstate system (urban + rural); OFA signifies other Federal-Aid system highways.

f Decreased $20 \%$ or more under three-year average rates reported in Table A.4.

g Increased $20 \%$ or more over three-year average rates reported in Table A.4. 
For railroads, reliable sources of empirical information and inference exist for both accidents and fatalities (numerator) and railcar-kilometers (denominator). The source for the numerator is the annual Accident/Incident Bulletin compiled from carrier reports by the U.S. Department of Transportation's (DOT's) Federal Railroad Administration (FRA) Office of Safety. This file (available on tape in a public-use version and supplemented by a published, annual summary of statistics) contains comprehensive, internally consistent descriptors for each accident, including the state of occurrence. The file is checked by the FRA for duplicate entries (more than one railroad involved in an accident), which are eliminated. By definition, an accident is a collision, derailment, or other event involving the operation of railroad on-track equipment and resulting in damages that exceed the reporting threshold. The 1985 through 1988 files are recent, complete annual records available for this study; therefore, we used these files for compiling a set of one four-year and four one-year estimates of rates (Table A.5).

\subsubsection{Flow Data}

The denominator of the unit-risk factor is total railcar-kilometers moved per unit of time. This figure is based on flow data for rail shipments and is calculated by state. The numerator and denominator yield the desired ratio of accident involvements per shipment kilometer.

Rail shipments, which move on dedicated, privately owned networks, are closely monitored by the carriers themselves through the manifests or waybills required for each shipment. The commodity, number of cars, and actual routing of the shipment are entered into a computer file, along with other data. The ICC requires that all railroads annually report on these shipments by submitting a representative, quality-checked sample of waybills (nominally $1 \%$, but actually higher). The ICC then processes these records into both proprietary data (carriers, origin, and destination points identified) and public-use data (only origin, interchange, and designation states identified). The public-use file for an average year contains well over 300,000 records; each record is drawn from a specific waybill and includes origin and destination regions, rail miles of the shipment, and (expanded) number of railcars loaded for that shipment.

We applied expansion factors to obtain a reliable estimate of the total (loaded) shipments in a given year. In its annual handbook, Railroad Facts, the Association of American Railroads $(1986,1987)$ reported the proportion of railcar-miles in the preceding year that were actually involved in shipments; by converting the waybill sample's railcarmiles to railcar-kilometers and dividing by this proportion (usually 50 to $60 \%$ ), we obtained total railcar-kilometers by origin and destination state.

Finally, these values (cars $\times$ kilometers) were assigned to the appropriate origin, destination, and intervening states. Shipments with origin and destination in the same state required only summation of the (factored) car-kilometers. We used a procedure developed for an earlier project on freight-network-flow forecasting for interstate shipments. During the time this study was conducted, a fully coded version of the FRA national rail network was 
kept on file at Argonne National Laboratory; this code included link-specific movement/ impedance costs by commodity type. The impedances appropriate for a typical commodity shipment of high value (but not premium service) were applied to develop a set of most probable flow factors for all interchanges among each of the 48 contiguous states (plus the District of Columbia). These vectors provide length information as well as actual fractions of each state-to-state vector on the rail network in origination, intervening, and destination states. Thus, an algorithm already constructed to manipulate such vectors was used to allocate each cell total of the state-to-state origin/destination matrix for year 1985 carkilometers across all appropriate states. This total was multiplied by the corresponding set of fractions and all state fractional allocations were summed into a car-kilometer total by state. These final 49 totals (48 states plus D.C.) became the denominators for the 1985 risk estimates.

Beginning with the 1986 waybill sample, the ICC no longer provided data about state origin and destination in the public-use file but included such information only at the more aggregated district level of the Bureau of Economic Aralysis. This is apparently due to a confidentiality requirement on public-use data; with the recent increase in railroad mergers and consolidations, some states are effectively served by only one rail carrier, and state-level data therefore become carrier-specific data, which remain proprietary. In order to develop 1986 unit-risk denominators consistent with the 1985 assignment procedure, it was necessary to use a secondary source of waybill information, namely Railroad Traffic in the United States, a compendium of statistics developed from the waybill sample and published annually by ALK Associates $(1986,1987,1988)$. Schematics of interstate railcar movements presented in the compendium, in conjunction with car-movement data from the edition of Railroad Facts covering 1986, served as the basis for expanding the 1985 state-level railcar-kilometer totals to 1986 estimated values. Comparison of 1985 and 1986 flow graphs in these publications enabled a reasonable determination of which states showed increased rail traffic, decreased traffic, or no net change; expansion factors were applied consistent with both these inferences and with the national control total presented in the 1986 compendium (ALK Associates 1988, p. 43).

\subsection{WATERWAY TRANSPORT BY BARGES AND OTHER MARINE VESSELS}

In the context of freight transport by domestic waterways, state borders have no significance. The characteristics of each wacerway are independent of the political jurisdictions through which that waterway passes, because a single national entity, the U.S. Army Corps of Engineers (the Corps), is responsible for maintenance over the entire navigable length of the waterway. Therefore, we made an administrative decision to use each geographic waterway system, rather than each state, as the basis for estimating unit-risk factors for water transport. The Corps manages tive waterway systems: Atlantic Coast, Gulf (of Mexico) Coast, Pacific Coast, Mississippi River (including the Arkansas, Ohio, Tennessee-Tombigbee, and Missouri navigable tributaries), and Great Lakes. 


\subsubsection{Accident Data}

The commercial vessel casualty file (CVCF) of the U.S. Coast Guard is the source of data for barge and other (revenue) marine-vessel accidents and damage on the domestic waterway system. Records are continuously compiled from reports of waterway situations in which:

1. Actual physical damage to property exceeds $\$ 25,000$;

2. Material damage affects the seaworthiness, maneuverability, or efficiency of a vessel;

3. A vessel is stranded or grounded (with or without damage);

4. Loss of life occurs; and/or

5. Injury occurs that causes any person to remain incapacitated for more than 72 hours, except injury to harbor workers not resulting in death and not resulting from vessel casualty or vessel equipment casualty.

The records include vessel characteristics, event, cause, total vessels/crafts involved in the incident, fatalities/injuries, and monetary damage; specific vessel codes indicate whether the vessel was carrying hazardous cargo (U.S. Coast Guard 1984).

We used the 1985 through 1988 CVCF in developing the numerators for waterborne unit-risk factors. (See Tables A.6 through A.11 in the Appendix.) All casualty records for the following vessel activities were included: break-in-bulk hauls, barge tow, bulk solid cargoes, oil tankerages, container hauls, roll-on roll-off cargoes, unclassified freight hauls, combination (mixed) freight hauls, gas carriers, ore or bulk-oil hauls, offshore transfers, bulk-liquidchemical hauls, and other unclassified or unknown freight.

All casualties, fatalities and injuries were tabulated by waterway system, from the output records. The Tennessee-Tombigbee Waterway was included in the Lower Mississippi system, rather than among Gulf Coastal waterways, because traffic on the "Tenn-Tom" in general represents an alternative to use of the Mississippi River and its tributaries. The total vessel involvement in each situation (greater than the casualty count) was obtained from each record in order to estimate the likelihood of a craft's involvement in accidentrelated delays (with no reportable damage sustained). For example, if only two barges in a tow of 22 sustain damage in an accident, the involvement count for that accident is 22 , but the casualty count is two and the accident count is one. Vessel counts include the total of dumb (non-self-propelled) barges.

\subsubsection{Flow Data}

Waterway movement statistics were obtained from the Corps' most recent annual reports on domestic waterborne commerce, which cover calendar years 1985 through 1988 
(U.S. Army Corps of Engineers 1987, 1988, 1989, 1990). Movement statistics are reported in tons and ton-miles by waterway; in order to convert these values to units consistent with those used in the highway and rail transport analysis, ton-miles were first converted to ton-kilometers by multiplication, then divided by a barge shipment weight that would be representative of future spent-fuel movements in large casks. Tobin, Meshkov, and Jones (1985) have estimated this value to be about 500 short tons. Thu?, dividing each waterway's ton-kilometer total by 500 yields the shipment-kilometer denominator needed for computing the unit-risk factor. These rates are shown at the bottom of Table A.10. 


\section{RESULTS}

Computed rates and statistical findings are discussed by mode in the sections below.

\subsection{HIGHWAY TRANSPORT}

Tables A.1 through A.3 present the accident-involvement (see Section 2.1) and fatality counts and estimated kilometers of travel for interstate-carrier, combination trucks, by states, for the three years investigated. Fatalities are deaths that are attributable to the accident and that occurred at any time within 30 days thereafter. Vehicle-kilometers of travel (VKT) can be converted to vehicle-miles of travel (VMT) by dividing by 1.609 .

Table A.4 shows the corresponding three-year-average rates for accident involvements, fatalities, and injuries sustained in the accidents. As described above, these rates are simply the counts of involvements, fatalities, and injuries within each state and road category, divided by the estimated kilometers of travel for interstate-registered, heavy combination trucks within that category. Especially high values (i.e, greater than twice the standard deviation of the distribution of rates for a given highway classification, given the total U.S. rate as the mean) are noted.

Although some of these higher values are affected by the fact that smaller states have fewer reported accidents, the highest accident rates in recent years for rural truck travel on the Federal-Aid Interstate system - meeting the $2 \times$ standard deviation criterion - have occurred in Connecticut, Massachusetts, and New Jersey. Interstate-truck travel in general shows the highest accident rates in New Jersey and New York, with the highest fatality rates in North Carolina. Shipments on urban portions of the Interstate system have had higher accident rates in Illinois, Maine, Montana, New Mexico, and South Dakota (the last four states having admittedly small and generally avoidable urban components).

Truck-shipment routing over the Federal-Aid Primary highways has been subject to the relatively highest accident and fatality exposures in Delaware and West Virginia. Interstate shipments using the Federal-Aid Secondary system are most likely to be near the pick-up or delivery end of their hauls, because these lower-echelon roads are generally not designed to meet heavy-duty line haul standards. Massachusetts and (for fatalities) Rhode Island are the two states that have experienced accident and fatality rates on this system more than two standard deviations higher than the national average.

With respect to accident counts on the Interstate system, no state had a year with a value greater than $140 \%$ of its three-year mean; the 12 highest excursions (in percentage difference) from the mean are shown in Table 2. All but two of these highest excursions occurred in 1988. Of the handful of states for which the highest yearly Interstate-system accident count over the period did not occur in 1988, most were located off the national 
TABLE 2 Highest One-Year Excursions from Three-Year Mean in Truck Accident Statistics, by State

\begin{tabular}{lccc}
\hline \multicolumn{1}{c}{ State } & $\begin{array}{c}\text { 1986-87-88 } \\
\text { Mean } \\
\text { I-State Count } \\
\text { of Accidents }\end{array}$ & $\begin{array}{c}\text { Highest } \\
\text { One-Year } \\
\text { Accident } \\
\text { Total }\end{array}$ & Year \\
\hline California & 487 & 611 & 1988 \\
North Carolina & 298 & 354 & 1988 \\
Arizona & 209 & 248 & 1988 \\
South Carolina & 170 & 205 & 1988 \\
New Mexico & 155 & 186 & 1987 \\
Massachusetts & 138 & 164 & 1988 \\
Nevada & 70 & 83 & 2988 \\
Idaho & 58 & 74 & 1988 \\
Maine & 41 & 50 & 1988 \\
North Dakota & 17 & 21 & 1986 \\
Rhode Island & 16 & 19 & 1988 \\
New Hampshire & 10 & 14 & 1988 \\
\hline
\end{tabular}

highway corridors that carry the highest truck flows. Because nationwide total combination-truck travel steadily increased year-to-year through the period, it may be inferred (but not conclusively demonstrated) that accident increases tracked truck-volume increases during the three years.

\subsection{RAILWAY TRANSPORT}

Table A.5a shows total and mainline-only accidents involving railcars, with estimated car-kilometers. Table A.5b shows total and mainline-only rail-freight accident rates, by state, for 1986,1987 , and 1988 , as well as a four-year-average rate for each state and for the United States, incorporating 1985 data (not shown). Nationwide average rates for fatalities and injuries were $6.50 \times 10^{-10}$ fatalities and $7.83 \times 10^{-8}$ injuries per railcarkilometer. Both rates were generally declining over the four-year period studied; fatality rate decreased by over $20 \%$ and injury rate by over $36 \%$. This reduction could not be attributed to the change in reporting threshold, because all fatality- and injury-causing events must be reported to FRA.

Because of the observed reduction in nationwide fatality and injury rates, we analyzed the variance in accident-involvement rates to assess whether a corresponding trend could be established. The result of this analysis was that a weighted accident rate (assigning greater significance to the most recent years' data) is not statistically different from the simple average rate over all four years, implying that there was no identifiable, net downward trend in rail-freight accident rates that would correspond to the decline in fatality and injury rates. Some states did experience an apparent accident-rate reduction during this 
time, but we could not exclude the possibility that this was due primarily to annual changes in the accident-cost-reporting threshold.

Several of the values in the columns headed "Main Only" in Table A.5b emphasize a key feature of rail operations at the state level: in most cases, bypassing rail-freight yards (for car classification and sorting) significantly reduces accident likelihood. Although rail-yard accidents are generally low-speed, low-impact events with limited damage to cargo, the relatively high total rail-accident rates for such major freight-interchange states as California, Illinois, and Texas, when compared to the corresponding "main only" rates, suggests that the extra delays in shipment time such incidents produce can be avoided by through hauls. Such hauls should in any case be more the rule than the exception for DOE waste shipments by rail.

Our analysis indicates that the four-year-average rates shown in Table A.5b will be reasonable approximations of state-level risk factors in hazardous waste for the next several years, except where low flows indicate that either national average rates or rates for contiguous states should be used.

\subsection{WATERWAY TRANSPORT}

Tables A.6 through A.10 report annual and four-year-average accident statistics for U.S. domestic waterways and coastal movements. Rates are computed for both accident involvements (total number of dumb and self-propelled vessels actually present in an accident, as described in Section 2.1) and casualties (dumb and self-propelled vessels sustaining damage) in order to be consistent with truck and rail rates, which include both damaged and undamaged shipments, and to acknowledge the importance of shipment delay due to an accident, even if no actual damage is sustained by the vessel.

Among inland waterways throughout the period analyzed, the Great Lakes experienced the lowest casualty rates, while Gulf Coast waterways experienced the highest. In terms of accident involvements, the Great Lakes again have the lowest rates, while the rates for Gulf Coast and Atlantic Coast waterways are approximately tied for highest. The accident-involvement and casualty rates for the Mississippi-Missouri system are low, relative to Gulf Coast rates.

By far the lowest accident-involvement and casualty rates are registered by coastwise shipping. Such shipments avoid congested waterways and are therefore subject to fewer delays (e.g., at locks and dams) and less restrictive clearances than their inland counterparts. The landborne equivalent to shipping along the coasts, with respect to relative freedom both from delay and from interaction with other freight movements, is probably through-rail hauling done by unit trains. However, we do not have separate data for unit-train accidents and flows; therefore, we cannot make a direct comparison.

For each waterway type, Table 3 (corresponding to Table 2, which shows highway accident counts) shows the year experiencing the highest excursion from the four-year mean 
for accident-involvement and casualty counts. The distribution of accident-involvement and casualty counts fails to establish any conclusive trend.

TABLE : Highest Excursions from the Four-Year Mean in Waterway Accident and Casualty Statistics

\begin{tabular}{|c|c|c|c|c|}
\hline \multirow[b]{2}{*}{ Waterway } & \multicolumn{2}{|c|}{ Accident Involvements } & \multicolumn{2}{|c|}{ Casualties } \\
\hline & $\begin{array}{l}\text { Year of } \\
\text { Maximum } \\
\text { Count }\end{array}$ & $\begin{array}{c}\text { Percent by } \\
\text { which Year's } \\
\text { Count Exceeded } \\
\text { 4-yr Mean for } \\
\text { Waterway }\end{array}$ & $\begin{array}{l}\text { Year ố } \\
\text { Maximum } \\
\text { Count }\end{array}$ & $\begin{array}{c}\text { Percent by } \\
\text { which Year's } \\
\text { Count Exceeded } \\
\text { 4-yr Mean for } \\
\text { Waterway }\end{array}$ \\
\hline Atlantic Coast & 1988 & 125 & 1988 & 111 \\
\hline Gulf Coast & 1988 & 121 & 1988 & 116 \\
\hline Pacific Coast & 1986 & 136 & 1986 & 132 \\
\hline Mississippi System & 1985 & 107 & 1985 & 115 \\
\hline Great Lakes & 1987 & 109 & 1985 & 108 \\
\hline Coastwise & 1988 & 137 & 1988 & 148 \\
\hline
\end{tabular}




\section{CONCLUSIONS AND SUGGESTIONS}

We have endeavored to improve the procedure by which disaggregate risk factors for transportation accidents, fatalities, and injuries are computed, for application to hazardouswaste shipments that may cross state lines. Our efforts have resulted in refinenent and revision of the rates (risk factors) documented in the publication Data Base of Accident and Agricultural Statistics for Transportation Risk Assessment (1989). Specifically, we have constructed a multiyear average covering recent-year data for relevant route categories on each of the three modes of interest (highway combination truck, rail freight, and waterway freight). We also have modified highway rates so that activity (flow) estimations are fully consistent with accident, fatality, and injury counts. Most updating procedures have also been automated in spreadsheet programs.

Although disaggregate (i.e., subnational) flow data of reasonably good quality are available for the rail and waterway modes, the same cannot be said for the highway-freight mode, which is still subject to substantial estimation error at the state level, leading to highly erratic year-to-year shifts in truck-flow volumes in several states. Thus, despite the high degree of quality control exercised in preparing highway-rate numerators, equivalent control

is not possible for the denominators. This knowledge led to the verification activities described in Section 2.1.3.

Our suggested actions are presented below, by transportation mode.

\subsection{HIGHWAY TRANSPORT}

- Continue to utilize, on an interim basis, highway risk factors that are based on the 1986-88 three-year-average rates shown in Table A.4 of this document.

- Continue to investigate and evaluate procedures to improve estimation of annual combination-truck highway mileage by state.

- If and when better estimation procedures become available, compute new state rates for those years using the 50-T compatibility adjustment described in this document.

\subsection{RAILWAY TRANSPORT}

- Four-year-average rail-accident rates computed for this report show reasonable stability; therefore, these rates could continue to be applied for an indefinite period (see Table A.5b). However, noteworthy changes in railroad operations, such as the formation of multimodal carriers and continuing consolidations among long-haul carriers, may progress to the point at which reexamination of annual data and reestimation of rates 
are warranted. In any case, reexamine the rates before final implementation of any major shipment program involving hazardous waste from DOE site-remediation cleanups.

- Apply national average or contiguous-state rates in those few states (and the District of Columbia) where low rail-traffic volumes produce extreme annual values for state-level rates; the latter rates are clearly unrepresentative and should not be included in any routing-decision process.

\subsection{WATERWAY TRANSPORT}

- Use the rates presented in Table A.10 of this document. These should prove adequate for the next several years.

- Monitor accident-involvement and casualty rates in Gulf Coastal waters. A significant increase in risk in these waterways could jeopardize any planning for extensive use of Gulf ports for waterborne hazardous-waste shipments. 


\section{REFERENCES}

ALK Associates, 1986, 1988, 1989, 1990, Railroad Traffic in the United States, editions for 1985-1988 inclusive, Princeton, N.J.

Anderson, B., 1993, McGil Special Services, personal communication, Oct. 29.

Association of American Railroads, 1986, 1987, 1988, Railroad Facts, annual publication, 1986-1988 inclusive, Office of Information and Public Affairs, Washington, D.C.

Cooney, J., 1993, Tri-State Motor Transit, personal communication, Oct. 29.

Federal Highway Administration, 1986, 1987, 1988, 1989, 1990, 1991, Highway Statistics, annual publication, Office of Highway Information Management publications FHWA-PL-88002, FHWA-PL-88-008, FHWA-PL-89-003 (covering 1986-1988 inclusive), and FHWA-PL-92025 (covering 1991), Washington, D.C.

Hu, P.S., et al., 1990, A Study of Interstate Motor Carrier Vehicle Miles of Travel, prepared by Oak Ridge National Laboratory for the Office of Motor Carriers Information, Federal Highway Administration, July [available from National Technical Information Service as publication no. DE90 016022].

Kirby, K., 1994, Hittman Transport, personal communication, Jan. 27.

Saricks, C.L., R.G.Williams, and M.R. Hopf, 1989, Data Base of Accident and Agricultural Statistics for Transportation Risk Assessment, Argonne National Laboratory Report ANL/EAIS/TM-2, Nov.

Shelton, T., 1993, Nuclear Assurance Corp., personal communication, Oct. 14.

Tobin, R.L., N.K. Meshkov, and R.H. Jones, 1985, Preliminary Assessment of the Costs and Risks of Transporting Spent Fuel by Barge, Argonne Nationai Laboratory Report ANL/ERTM-85-2, Dec.

U.S. Army Corps of Engineers, 1987, Waterborne Commerce of the United States - Calendar Year 1985, annual publication WRSC-WCUS-85 (Vol. 5), New Orleans, La.

U.S. Army Corps of Engineers, 1988, Waterborne Commerce of the United States - Calendar Year 1986, annual publication WRSC-WCUS-86 (Vol. 5), New Orleans, La.

U.S. Army Corps of Engineers, 1989, Waterborne Commerce of the United States - Calendar Year 1987, annual publication WRSC-WCUS-87 (Vol. 5), New Orleans, La.

U.S. Army Corps of Engineers, 1990, Waterborne Commerce of the United States - Calendar Year 1988, annual publication WRSC-WCUS-88 (Vol. 5), New Orleans, La. 
U.S. Bureau of the Census, 1987, Truck Inventory and Use Survey, public-use tapes, Washington, D.C.

U.S. Coast Guard, 1984, Coding Instructions for the Automated File of Commercial Vessel Casualties, Washington, D.C., Feb.

U.S. Department of Transportation, 1986, 1987, 1988, Accident/Incident Bulletin, annual publication, Ftderal Railroad Administration, Office of Safety, Washington, D.C. 
APPENDIX:

ACCIDENT STATISTICS AND RATE TABLES 
TABLE A.1 Reportable Highway Combination-Truck Accidents, Fatalities, and Estimated Flows, by State and by Road Type, $1^{1986}{ }^{a}$

\begin{tabular}{|c|c|c|c|c|c|c|c|c|c|c|c|c|c|c|c|}
\hline \multirow[b]{2}{*}{ State $^{b}$} & \multicolumn{5}{|c|}{$\begin{array}{l}\text { Combination-Truck Accidents Reported by } \\
\text { Interstate Carriers }\end{array}$} & \multicolumn{5}{|c|}{$\begin{array}{l}\text { Heavy-Truck Aocident Fatalities Reported } \\
\text { by Interstate Carriers }\end{array}$} & \multicolumn{5}{|c|}{$\begin{array}{c}\text { Est. Interstate-Registered Motor-Carrier, } \\
\text { Combination Truck km }\left(10^{6}\right)\end{array}$} \\
\hline & FAI-U & FAI-R & FAI & FAP & FAS & FAI-U & FAI-R & FAI & FAP & FAS & FAI-U & FAI-R & FAI & FAP & FAS \\
\hline $\mathrm{AL}$ & 78 & 98 & 176 & 228 & 49 & 2 & 19 & 21 & 20 & 10 & 158 & 809 & 967 & 413 & 83 \\
\hline $\mathrm{AZ}$ & 39 & 142 & 181 & 49 & 10 & 5 & 18 & 23 & 13 & 0 & 162 & 822 & 984 & 139 & 22 \\
\hline $\mathrm{AR}$ & 57 & 108 & 165 & 195 & 34 & 5 & 19 & 24 & 40 & 3 & 114 & 519 & 633 & 397 & 27 \\
\hline $\mathrm{CA}$ & 223 & 170 & 393 & 307 & 16 & 12 & 34 & 46 & 54 & 4 & 1239 & 1383 & 2622 & 2144 & 89 \\
\hline CO & 56 & 62 & 118 & 83 & 17 & 3 & 7 & 10 & 12 & 3 & 115 & 295 & 410 & 221 & 34 \\
\hline CT & 165 & 44 & 209 & 39 & 11 & 7 & 12 & 19 & 2 & 2 & 516 & 214 & 730 & 52 & 15 \\
\hline $\mathrm{DE}$ & 21 & - & 21 & 37 & 4 & 1 & . & 1 & 5 & 1 & 94 & 0 & 94 & 47 & 7 \\
\hline FL & 118 & 102 & 220 & 301 & 43 & 5 & 27 & 32 & 40 & 6 & 562 & 1273 & 1835 & 656 & 56 \\
\hline GA & 192 & 184 & 376 & 273 & 44 & 8 & 18 & 26 & 30 & 6 & 355 & 1393 & 1748 & 591 & 62 \\
\hline ID & 9 & 43 & 52 & 40 & 7 & 0 & 5 & 5 & 8 & 3 & 34 & 223 & 257 & 77 & 41 \\
\hline II & 472 & 191 & 663 & 312 & 13 & 21 & 17 & 38 & 41 & 0 & 430 & 1360 & 1790 & 506 & 114 \\
\hline IN & 273 & 172 & 445 & 378 & 35 & 27 & 11 & 38 & 73 & 3 & 346 & 1332 & 1678 & 739 & 154 \\
\hline IA & 40 & 124 & 164 & 139 & 16 & 3 & 2 & 5 & 17 & 1 & 103 & 682 & 785 & 349 & 43 \\
\hline $\mathrm{KS}$ & 57 & 63 & 120 & 177 & 1 & 3 & 10 & 13 & 35 & 0 & 91 & 314 & 405 & 336 & 35 \\
\hline $\mathrm{KY}$ & 87 & 110 & 197 & 107 & 55 & 8 & 11 & 19 & 14 & 4 & 139 & 884 & 1023 & 194 & 59 \\
\hline LA & 75 & 78 & 153 & 146 & 30 & 6 & 14 & 20 & 25 & 6 & 273 & 591 & 864 & 437 & 180 \\
\hline $\mathrm{ME}$ & 14 & 22 & 36 & 32 & 4 & 0 & 2 & 2 & 5 & 0 & 10 & 109 & 119 & 78 & 27 \\
\hline $\mathrm{MD}$ & 154 & 76 & 230 & 141 & 19 & 12 & 7 & 19 & 18 & 2 & 433 & 364 & 797 & 403 & 30 \\
\hline MA & 53 & 53 & 106 & 43 & 28 & 7 & 10 & 17 & 5 & 7 & 157 & 135 & 292 & 135 & 9 \\
\hline MI & 179 & 98 & 277 & 175 & 3 & 11 & 3 & 14 & 25 & 2 & 547 & 1027 & 1574 & 582 & 50 \\
\hline $\mathrm{MN}$ & 45 & 54 & 99 & 130 & 17 & 3 & 5 & 8 & 35 & 3 & 91 & 254 & 345 & 346 & 93 \\
\hline MS & 33 & 55 & 88 & 187 & 11 & 2 & 7 & 9 & 49 & 4 & 96 & 533 & 629 & 366 & 143 \\
\hline MO & 173 & 148 & 321 & 236 & 34 & 14 & 11 & 25 & 42 & 2 & 226 & 913 & 1139 & 432 & 70 \\
\hline MT & 18 & 48 & 66 & 53 & 3 & 0 & 5 & 5 & 9 & 1 & 10 & 191 & 201 & 107 & 11 \\
\hline $\mathrm{NE}$ & 21 & 56 & 77 & 69 & 2 & 4 & 4 & 8 & 7 & 0 & 24 & 368 & 392 & 208 & 34 \\
\hline NV & 19 & 42 & 61 & 24 & 5 & 4 & 6 & 10 & 6 & 2 & 42 & 279 & 321 & 59 & 26 \\
\hline NH & 0 & 6 & 6 & 26 & 7 & 0 & 1 & 1 & 5 & 0 & 15 & 62 & 77 & 30 & 43 \\
\hline $\mathrm{NJ}$ & 140 & 149 & 289 & 214 & 29 & 7 & 18 & 25 & 16 & 5 & 705 & 216 & 921 & 244 & 21 \\
\hline NM & 24 & 97 & 121 & 57 & 7 & 6 & 7 & 13 & 10 & 0 & 61 & 534 & 595 & 90 & 7 \\
\hline$N Y$ & 212 & 211 & 423 & 217 & 74 & 3 & 11 & 14 & 35 & 5 & 340 & 589 & 929 & 646 & 52 \\
\hline $\mathrm{NC}$ & 111 & 133 & 244 & 287 & 97 & 13 & 14 & 27 & 55 & 17 & 161 & 688 & 849 & 591 & 179 \\
\hline ND & 3 & 18 & 21 & 24 & 0 & 0 & 0 & 0 & 1 & 0 & 7 & 144 & 151 & 106 & 8 \\
\hline $\mathrm{OH}$ & 199 & 397 & 596 & 368 & 101 & 6 & 27 & 33 & 29 & 4 & 605 & 1994 & 2599 & 1097 & 210 \\
\hline OK & 60 & 74 & 134 & 136 & 25 & 3 & 14 & 17 & 13 & 2 & 158 & 676 & 844 & 333 & 111 \\
\hline OR & 36 & 128 & 164 & 130 & 9 & 2 & 8 & 10 & 25 & 1 & 88 & 470 & 558 & 266 & 23 \\
\hline $\mathrm{PA}$ & 151 & 565 & 716 & 496 & 53 & 6 & 39 & 45 & 66 & 5 & 462 & 1769 & 2231 & 720 & 74 \\
\hline $\mathrm{RI}$ & 13 & 5 & 18 & 5 & 2 & 0 & 0 & 0 & 0 & 1 & 36 & 17 & 53 & 14 & 1 \\
\hline
\end{tabular}


TABLE A.1 (Cont.)

\begin{tabular}{|c|c|c|c|c|c|c|c|c|c|c|c|c|c|c|c|}
\hline \multirow[b]{2}{*}{ State $^{b}$} & \multicolumn{5}{|c|}{$\begin{array}{l}\text { Combination-Truck Accidents Reported by } \\
\text { Interstate Carriers }\end{array}$} & \multicolumn{5}{|c|}{$\begin{array}{l}\text { Heavy-Truck Accident Fatalities Reported } \\
\text { by Interstate Carriers }\end{array}$} & \multicolumn{5}{|c|}{$\begin{array}{c}\text { Est. Interstate-Registered Motor-Carrier, } \\
\text { Combination Truck } \mathrm{km}\left(10^{6}\right)\end{array}$} \\
\hline & FAI-U & FAI-R & FAI & FAP & FAS & FAI-U & FAI-R & FAI & FAP & FAS & FAI-U & FAI-R & FAI & FAP & FAS \\
\hline SC & 22 & 108 & 130 & 177 & 19 & 4 & 16 & 20 & 25 & 2 & 87 & 668 & 755 & 384 & 128 \\
\hline $\mathrm{SD}$ & 0 & 32 & 32 & 41 & 1 & 0 & 1 & 1 & 8 & 0 & 3 & 213 & 216 & 136 & 25 \\
\hline $\mathrm{TN}$ & 154 & 185 & 339 & 199 & 8 & 7 & 16 & 23 & 26 & 0 & 288 & 1488 & 1776 & 311 & 38 \\
\hline $\mathrm{TX}$ & 291 & 272 & 563 & 461 & 54 & 13 & 24 & 37 & 79 & 5 & 1300 & 2172 & 3472 & 1496 & 419 \\
\hline UT & 23 & 79 & 102 & $\begin{array}{r}401 \\
45\end{array}$ & 4 & 0 & $\begin{array}{r}27 \\
8\end{array}$ & 8 & 12 & 0 & 98 & 309 & 407 & 95 & 15 \\
\hline VT & 0 & 12 & 12 & 26 & 4 & 0 & 0 & 0 & 1 & 2 & 3 & 72 & 75 & 47 & 7 \\
\hline VA & 75 & 224 & 299 & 230 & 30 & 3 & 11 & 14 & 44 & 5 & 285 & 777 & 1062 & 545 & 35 \\
\hline WA & 38 & 106 & 144 & 80 & 11 & 2 & 2 & 4 & 8 & 0 & 270 & 369 & 639 & 256 & 133 \\
\hline WV & 25 & 100 & 125 & 130 & 21 & 0 & 9 & 9 & 13 & 7 & 58 & 290 & 348 & 90 & 57 \\
\hline WI & 50 & 111 & 161 & 192 & 12 & 0 & 5 & 5 & 20 & 1 & 85 & 526 & 611 & 661 & 27 \\
\hline WY & 14 & 145 & 159 & 41 & 5 & 0 & 5 & 5 & 3 & 1 & 12 & 389 & 401 & 121 & 25 \\
\hline USA & 4312 & 5500 & 9812 & 7483 & 1084 & 248 & 520 & 768 & 1124 & 138 & 10837 & 31955 & 42792 & 18294 & 3150 \\
\hline
\end{tabular}

a Accidents $=$ Accident involvements of heavy combination trucks,

Fatalities $=$ Accident-related deaths occurring up to 30 days after date of accident,

FAI-U = Federal-Aid Interstate highway system in urbanized areas,

FAI-R = Federal-Aid Interstate highway system in rural areas,

FAI = Federal-Aid Interstate highway system (urban and rural combined),

FAP $=$ Federal-Aid primary highway system, and

FAS = Federal-Aid secondary (rural) highway system.

b Includes only the 48 contiguous states, plus the totals for the nation as a whole (USA). 
TABLE A.2 Reportable Highway Combination-Truck Accidents, Fatalities, and Estimated Flows, by State and by Road Type, $1987^{\mathrm{a}}$

\begin{tabular}{|c|c|c|c|c|c|c|c|c|c|c|c|c|c|c|c|}
\hline \multirow[b]{2}{*}{ State $^{b}$} & \multicolumn{5}{|c|}{$\begin{array}{l}\text { Combination-Truck Accidents Reported by } \\
\text { Interstate Carriers }\end{array}$} & \multicolumn{5}{|c|}{$\begin{array}{l}\text { Heavy-Truck Accident Fatalities Reported by } \\
\text { Interstate Carriers }\end{array}$} & \multicolumn{5}{|c|}{$\begin{array}{l}\text { Est. Interstate-Registered Motor-Carrier, } \\
\text { Combination Truck km }\left(10^{6}\right)\end{array}$} \\
\hline & FAI-U & FAI-R & FAI & FAP & FAS & FAI-U & FAI-R & FAI & FAP & FAS & FAl-U & FAI-R & FAI & FAP & FAS \\
\hline $\mathrm{AL}$ & 79 & 113 & 192 & 243 & 26 & 7 & 8 & 15 & 37 & 8 & 168 & 894 & 1062 & 453 & 87 \\
\hline $\mathrm{AZ}$ & 46 & 152 & 198 & 51 & 10 & 8 & 23 & 31 & 6 & 2 & 194 & 1227 & 1421 & 210 & 55 \\
\hline $\mathrm{AR}$ & 35 & 92 & 127 & 217 & 38 & 0 & 7 & 7 & 41 & 3 & 80 & 724 & 804 & 453 & 62 \\
\hline CA & 212 & 245 & 457 & 303 & 26 & 22 & 27 & 49 & 55 & 3 & 1239 & 1684 & 2923 & 2346 & 108 \\
\hline $\mathrm{CO}$ & 71 & 92 & 163 & 82 & 21 & 1 & 10 & 11 & 16 & 2 & 67 & 273 & 340 & 143 & 35 \\
\hline CT & 120 & 103 & 223 & 36 & 19 & 4 & 9 & 13 & 1 & 0 & 539 & 228 & 767 & 189 & 17 \\
\hline $\mathrm{DE}$ & 29 & - & 29 & 41 & 9 & 1 & - & 1 & 9 & 3 & 97 & 0 & 97 & 65 & 24 \\
\hline FL & 99 & 154 & 253 & 310 & 44 & 13 & 33 & 46 & 49 & 4 & 297 & 1189 & 1486 & 950 & 92 \\
\hline GA & 151 & 234 & 385 & 316 & 32 & 8 & 24 & 32 & 39 & 7 & 511 & 1296 & 1807 & 454 & 72 \\
\hline ID & 5 & 44 & 49 & 42 & 10 & 0 & 3 & 3 & 5 & 0 & 39 & 202 & 241 & 78 & 45 \\
\hline IL & 418 & 304 & 722 & 294 & 21 & 26 & 15 & 41 & 35 & 3 & 533 & 1577 & 2110 & 473 & 92 \\
\hline IN & 117 & 328 & 445 & 438 & 53 & 8 & 13 & 21 & 76 & 9 & 388 & 1759 & 2147 & 1187 & 153 \\
\hline IA & 36 & 119 & 155 & 136 & 1 & 3 & 4 & 7 & 20 & 0 & 109 & 709 & 818 & 358 & 45 \\
\hline KS & 41 & 71 & 112 & 178 & 6 & 8 & 6 & 14 & 44 & 0 & 105 & 375 & 480 & 347 & 38 \\
\hline KY & 66 & 134 & 200 & 122 & 60 & 2 & 13 & 15 & 11 & 4 & 152 & 886 & 1038 & 223 & 64 \\
\hline LA & 77 & 84 & 161 & 147 & 44 & 17 & 14 & 31 & 20 & 5 & 217 & 698 & 915 & 376 & 167 \\
\hline ME & 6 & 30 & 36 & 40 & 7 & 0 & 1 & 1 & 2 & 0 & 11 & 133 & 144 & 72 & 29 \\
\hline $\mathrm{MD}$ & 101 & 176 & 277 & 117 & 46 & 6 & 19 & 25 & 11 & 2 & 359 & 397 & 756 & 413 & 32 \\
\hline MA & 52 & 91 & 143 & 57 & 39 & 5 & 3 & 8 & 6 & 2 & 569 & 61 & 630 & 165 & 2 \\
\hline MI & 126 & 167 & 293 & 157 & 8 & 2 & 14 & 16 & 26 & 0 & 421 & 916 & 1337 & 561 & 94 \\
\hline MN & 38 & 51 & 89 & 118 & 15 & 4 & 4 & 8 & 20 & 2 & 196 & 268 & 464 & 294 & 55 \\
\hline MS & 28 & 79 & 107 & 169 & 20 & 1 & 16 & 17 & 29 & 5 & 234 & 745 & 979 & 502 & 111 \\
\hline MO & 160 & 159 & 319 & 274 & 38 & 21 & 10 & 31 & 51 & 10 & 263 & 941 & 1204 & 419 & 77 \\
\hline $\mathrm{MT}$ & 7 & 46 & 53 & 52 & 0 & 1 & 2 & 3 & 10 & 0 & 10 & 225 & 235 & 92 & 13 \\
\hline NE & 17 & 76 & 93 & 89 & 5 & 0 & 4 & 4 & 17 & 0 & 26 & 384 & 410 & 210 & 34 \\
\hline NV & 17 & 48 & 65 & 30 & 9 & 1 & 5 & 6 & 5 & 3 & 24 & 338 & 362 & 63 & 19 \\
\hline NH & 0 & 9 & 9 & 30 & 7 & 0 & 1 & 1 & 4 & 0 & 17 & 67 & 84 & 56 & 18 \\
\hline NJ & 149 & 213 & 362 & 216 & 30 & 11 & 17 & 28 & 9 & 1 & 369 & 215 & 584 & 257 & 32 \\
\hline NM & 40 & 146 & 186 & 54 & 5 & 1 & 18 & 19 & 9 & 0 & 19 & 602 & 621 & 101 & 6 \\
\hline $\mathrm{NY}$ & 279 & 193 & 472 & 195 & 59 & 13 & 11 & 24 & 32 & 10 & 452 & 783 & 1235 & 581 & 67 \\
\hline NC & 112 & 183 & 295 & 286 & 106 & 10 & 17 & 27 & 28 & 18 & 187 & 744 & 931 & 436 & 129 \\
\hline ND & 0 & 12 & 12 & 17 & 1 & 0 & 1 & 1 & 0 & 0 & 10 & 141 & 151 & 108 & 34 \\
\hline $\mathrm{OH}$ & 218 & 432 & 650 & 456 & 138 & 16 & 20 & 36 & 68 & 11 & 900 & 1940 & 2840 & 972 & 44 \\
\hline OK & 60 & 123 & 183 & 137 & 26 & 5 & 14 & 19 & 27 & 1 & 156 & 662 & 818 & 380 & 142 \\
\hline OR & 38 & 82 & 120 & 124 & 4 & 3 & 3 & 6 & 15 & 0 & 95 & 461 & 556 & 331 & 48 \\
\hline
\end{tabular}


TABLE A.2 (Cont.)

\begin{tabular}{|c|c|c|c|c|c|c|c|c|c|c|c|c|c|c|c|}
\hline \multirow[b]{2}{*}{ State $^{b}$} & \multicolumn{5}{|c|}{$\begin{array}{l}\text { Combination-Truck Accidents Reported by } \\
\text { Interstate Carriers }\end{array}$} & \multicolumn{5}{|c|}{$\begin{array}{l}\text { Heavy-Truck Accident Fatalities Reported by } \\
\text { Interstate Carriers }\end{array}$} & \multicolumn{5}{|c|}{$\begin{array}{l}\text { Est. Interstate-Registered Motor-Carrier, } \\
\text { Combination Truck km }\left(10^{6}\right) \\
\end{array}$} \\
\hline & FAI-U & FAI-R & FAI & FAP & FAS & FAI-U & FAl-R & FAI & FAP & FAS & FAI-U & FAI-R & FAI & FAP & FAS \\
\hline PA & 170 & 649 & 819 & 530 & 60 & 10 & 60 & 70 & 76 & 6 & 487 & 1801 & 2288 & 744 & 74 \\
\hline $\mathrm{RI}$ & 6 & 5 & 11 & 4 & 1 & 0 & 2 & 2 & 1 & 1 & 39 & 18 & 57 & 21 & 1 \\
\hline TN & 235 & 234 & 469 & 173 & 26 & 14 & 30 & 44 & 19 & 7 & 286 & 1315 & 1601 & 347 & 26 \\
\hline $\mathrm{TX}$ & 337 & 311 & 648 & 444 & 55 & 36 & 40 & 76 & 81 & 14 & 1133 & 2037 & 3170 & 1615 & 486 \\
\hline UT & 26 & 71 & 97 & 38 & 8 & 1 & 5 & 6 & 7 & 0 & 114 & 326 & 440 & 97 & 15 \\
\hline VT & 0 & 9 & 9 & 27 & 6 & 0 & 0 & 0 & 2 & 1 & 3 & 78 & 81 & 35 & 10 \\
\hline VA & 82 & 241 & 323 & 217 & 25 & 3 & 17 & 20 & 35 & 1 & 229 & 1058 & 1287 & 487 & 50 \\
\hline WA & 47 & 73 & 120 & 76 & 8 & 3 & 10 & 13 & 8 & 0 & 290 & 351 & 641 & 245 & 127 \\
\hline Wv & 21 & 107 & 128 & 126 & 32 & 1 & 3 & 4 & 22 & 2 & 83 & 280 & 363 & 116 & 11 \\
\hline WI & 34 & 100 & 134 & 204 & 19 & 0 & 2 & 2 & 29 & 3 & 82 & 539 & 621 & 732 & 30 \\
\hline WY & 0 & 143 & 143 & 33 & 14 & 0 & 10 & 10 & 3 & 1 & 18 & 406 & 424 & 119 & 26 \\
\hline USA & 4046 & 6699 & 10745 & 7674 & 1261 & 299 & 589 & 888 & 1148 & 162 & 11927 & 32806 & 44733 & 19236 & 3082 \\
\hline
\end{tabular}

a Accidents = Accident involvements of heavy combination trucks,

Fatalities $=$ Accident-related deaths occurring up to 30 days after date of accident,

FAI-U = Federal-Aid Interstate highway system in urbanized areas,

FAI-R = Federal-Aid Interstate highway system in rural areas,

FAI = Federal-Aid Interstate highway system (urban and rural combined),

FAP = Federal-Aid primary highway system, and

FAS = Federal-Aid secondary (rural) highway system .

b Includes only the 48 contiguous states, plus the totals for the nation as a whole (USA). 
TABLE A.3 Reportable Highway Combination-Truck Accidents, Fatalities, and Estimated Flows, by State and by Road Type, $1988^{a}$

\begin{tabular}{|c|c|c|c|c|c|c|c|c|c|c|c|c|c|c|c|}
\hline \multirow[b]{2}{*}{ State $^{\mathrm{b}}$} & \multicolumn{5}{|c|}{$\begin{array}{l}\text { Combination-Truck Accidents Reported by } \\
\text { Interstate Carriers }\end{array}$} & \multicolumn{5}{|c|}{$\begin{array}{l}\text { Heavy-Truck Accident Fatalities Reported by } \\
\text { Interstate Carriers }\end{array}$} & \multicolumn{5}{|c|}{$\begin{array}{l}\text { Est. Interstate-Registered, Motor-Carrier, } \\
\text { Combination-Truck km }\left(10^{6}\right)\end{array}$} \\
\hline & FAI-U & FAI-R & FAI & FAP & FAS & FAI-U & FAI-R & FAI & FAP & FAS & FAI-U & FAI-R & FAI & FAP & FAS \\
\hline $\mathrm{AL}$ & 99 & 117 & 216 & 253 & 31 & 9 & 21 & 30 & 32 & 3 & 221 & 904 & 1125 & 538 & 98 \\
\hline $\mathrm{AZ}$ & 52 & 196 & 248 & 49 & 4 & 5 & 24 & 29 & 16 & 0 & 150 & 1004 & 1154 & 355 & 89 \\
\hline $\mathrm{AR}$ & 32 & 135 & 167 & 190 & 34 & 12 & 18 & 30 & 33 & 5 & 63 & 691 & 754 & 434 & 66 \\
\hline $\mathrm{CA}$ & 243 & 368 & 611 & 299 & 28 & 15 & 61 & 76 & 47 & 5 & 1058 & 1706 & 2764 & 3405 & 118 \\
\hline $\mathrm{CO}$ & 59 & 105 & 164 & 85 & 15 & 6 & 6 & 12 & 12 & 2 & 114 & 372 & 486 & 244 & 51 \\
\hline $\mathrm{CT}$ & 111 & 132 & 243 & 35 & 20 & 4 & 10 & 14 & 2 & 3 & 429 & 165 & 594 & 188 & 23 \\
\hline $\mathrm{DE}$ & 27 & - & 27 & 47 & 12 & 3 & - & 3 & 9 & 0 & 110 & 0 & 110 & 58 & 21 \\
\hline FL & 94 & 184 & 278 & 323 & 68 & 6 & 35 & 41 & 59 & 5 & 523 & 1163 & 1686 & 895 & 97 \\
\hline GA & 150 & 265 & 415 & 330 & 32 & 8 & 35 & 43 & 55 & 5 & 146 & 1450 & 1596 & 449 & 133 \\
\hline ID & 5 & 69 & 74 & 50 & 10 & 0 & 6 & 6 & 7 & 0 & 37 & 253 & 290 & 113 & 32 \\
\hline II & 456 & 306 & 762 & 349 & 20 & 35 & 31 & 66 & 41 & 4 & 405 & 1415 & 1820 & 506 & 98 \\
\hline IN & 133 & 412 & 545 & 454 & 65 & 5 & 34 & 39 & 57 & 10 & 407 & 1670 & 2077 & 764 & 240 \\
\hline IA & 43 & 149 & 192 & 165 & 0 & 3 & 17 & 20 & 30 & 0 & 124 & 807 & 931 & 385 & 49 \\
\hline $\mathrm{KS}$ & 32 & 83 & 115 & 192 & 9 & 5 & 4 & 9 & 21 & 2 & 94 & 375 & 469 & 387 & 43 \\
\hline $\mathrm{KY}$ & 86 & 155 & 241 & 145 & 54 & 5 & 17 & 22 & 18 & 4 & 175 & 969 & 1144 & 235 & 69 \\
\hline $\mathrm{LA}$ & 94 & 94 & 188 & 138 & 50 & 11 & 7 & 18 & 25 & 6 & 204 & 684 & 888 & 409 & 172 \\
\hline ME & 8 & 42 & 50 & 52 & 10 & 0 & 6 & 6 & 8 & 2 & 10 & 143 & 153 & 78 & 36 \\
\hline MD & 126 & 140 & 266 & 122 & 45 & 2 & 14 & 16 & 10 & 4 & 446 & 232 & 678 & 250 & 27 \\
\hline MA & 59 & 105 & 164 & 66 & 39 & 3 & 11 & 14 & 8 & 3 & 431 & 192 & 623 & 184 & 12 \\
\hline MI & 132 & 176 & 308 & 181 & 9 & 8 & 17 & 25 & 25 & 1 & 416 & 1069 & 823 & 774 & 102 \\
\hline $\mathrm{MN}$ & 49 & 63 & 112 & 155 & 12 & 3 & 5 & 8 & 19 & 11 & 209 & 292 & 501 & 322 & 56 \\
\hline MS & 29 & 89 & 118 & 201 & 5 & 8 & 11 & 19 & 37 & 0 & 118 & 601 & 719 & 374 & 303 \\
\hline MO & 173 & 225 & 398 & 277 & 43 & 7 & 16 & 23 & 49 & 3 & 488 & 1143 & 1631 & 616 & 315 \\
\hline MT & 7 & 64 & 71 & 57 & 2 & 0 & 2 & 2 & 5 & 0 & 12 & 210 & 222 & 102 & 25 \\
\hline $\mathrm{NE}$ & 15 & 78 & 93 & 81 & 4 & 1 & 5 & 6 & 14 & 0 & 26 & 432 & 458 & 243 & 43 \\
\hline NV & 21 & 62 & 83 & 29 & 6 & 3 & 0 & 3 & 9 & 0 & 24 & 352 & 376 & 69 & 18 \\
\hline NH & 1 & 13 & 14 & 12 & 10 & 0 & 1 & 1 & 0 & 4 & 13 & 72 & 85 & 70 & 11 \\
\hline NJ & 155 & 163 & 318 & 209 & 34 & 7 & 10 & 17 & 18 & 5 & 528 & 255 & 783 & 439 & 43 \\
\hline NM & 43 & 116 & 159 & 46 & 10 & 3 & 11 & 14 & 4 & 1 & 31 & 732 & 763 & 138 & 5 \\
\hline NY & 236 & 211 & 447 & 240 & 51 & 10 & 7 & 17 & 28 & 5 & 485 & 725 & 1210 & 834 & 75 \\
\hline NC & 115 & 239 & 354 & 289 & 132 & 6 & 40 & 46 & 29 & 23 & 223 & 1001 & 1224 & 641 & 218 \\
\hline ND & 8 & 11 & 19 & 20 & 2 & 1 & 1 & 2 & 2 & 0 & 8 & 130 & 138 & 92 & 34 \\
\hline $\mathrm{OH}$ & 254 & 443 & 697 & 518 & 129 & 8 & 27 & 35 & 87 & 18 & 621 & 1662 & 2283 & 964 & 80 \\
\hline OK & 61 & 102 & 163 & 141 & 22 & 5 & 14 & 19 & 16 & 0 & 168 & 699 & 867 & 434 & 169 \\
\hline OR & 39 & 125 & 164 & 152 & 7 & 2 & 6 & 8 & 17 & 4 & 100 & 589 & 689 & 377 & 52 \\
\hline
\end{tabular}


TABLE A.3 (Cont.)

\begin{tabular}{|c|c|c|c|c|c|c|c|c|c|c|c|c|c|c|c|}
\hline \multirow[b]{2}{*}{ State $^{b}$} & \multicolumn{5}{|c|}{$\begin{array}{l}\text { Combination-Truck Accidents Reported by } \\
\text { Interstate Carriers }\end{array}$} & \multicolumn{5}{|c|}{$\begin{array}{l}\text { Heavy-Truck Accident Fatalities Reported by } \\
\text { Interstate Carriers }\end{array}$} & \multicolumn{5}{|c|}{$\begin{array}{l}\text { Est. Interstate-Registered, Motor-Carrier, } \\
\text { Combination-Truck km }\left(10^{6}\right)\end{array}$} \\
\hline & FAI-U & FAI-R & FAI & FAP & FAS & FAI-U & FAI-R & FAI & FAP & FAS & FAI-U & FAI-R & FAI & FAP & FAS \\
\hline $\mathrm{PA}$ & 121 & 734 & 855 & 600 & 66 & 15 & 62 & 77 & 87 & 10 & 515 & 1842 & 2357 & 790 & 78 \\
\hline $\mathrm{RI}$ & 13 & 6 & 19 & 7 & 2 & 1 & 1 & 2 & 1 & 0 & 66 & 46 & 112 & 82 & 1 \\
\hline TN & 267 & 244 & 511 & 210 & 33 & 25 & 27 & 52 & 28 & 6 & 249 & 1683 & 1932 & 389 & 43 \\
\hline $\mathrm{TX}$ & 381 & 383 & 764 & 539 & 62 & 22 & 58 & 80 & 88 & 10 & 1250 & 1998 & 3248 & 2092 & 668 \\
\hline UT & 36 & 90 & 126 & 29 & 11 & 1 & 9 & 10 & 6 & 1 & 125 & 362 & 487 & 111 & 16 \\
\hline $\mathrm{VT}$ & 0 & 11 & 11 & 22 & 7 & 0 & 1 & 1 & 1 & 3 & 3 & 82 & 85 & 37 & 8 \\
\hline VA & 77 & 227 & 304 & 253 & 36 & 11 & 20 & 31 & 30 & 8 & 375 & 893 & 1268 & 466 & 96 \\
\hline WA & 56 & 93 & 149 & 81 & 11 & 2 & 4 & 6 & 7 & 0 & 317 & 368 & 685 & 404 & 150 \\
\hline WV & 23 & 108 & 131 & 131 & 21 & 2 & 5 & 7 & 24 & 7 & 93 & 446 & 539 & 126 & 26 \\
\hline WI & 54 & 105 & 159 & 208 & 13 & 2 & 5 & 7 & 29 & 1 & 94 & 754 & 848 & 764 & 79 \\
\hline WY & 0 & 188 & 188 & 52 & 11 & 0 & 14 & 14 & 17 & 1 & 17 & 598 & 615 & 130 & 30 \\
\hline USA & 4319 & 7628 & 11947 & 8324 & 1329 & 293 & 758 & 1051 & 1196 & 188 & 12011 & 34174 & 46185 & 22082 & 4332 \\
\hline
\end{tabular}

a Accidents $=$ Accident involvements of heavy combination trucks,

Fatalities = Accident-related deaths occurring up to 30 days after date of accident,

FAI-U = Federal-Aid Interstate highway system in urbanized areas,

FAI-R = Federal-Aid Interstate highway system in rural areas,

FAI = Federal-Aid Interstate highway system (urban and rural combined),

FAP = Federal-Aid primary highway system, and

FAS = Federal-Aid secondary (rural) highway system .

b Includes only the 48 contiguous states, plus the totals for the nation as a whole (USA). 
TABLE A.4 Highway Combination-Truck Accident, Fatality, and Injury Rates Based on Reportable Interstate-Carrier Accidents, Reported Fatalities and Injuries, and Estimated Flows, 1986-1988 (10 ${ }^{-7}$ accidents and injuries per shipmentkilometer, $10^{-8}$ fatalities per shipment-kilometer)

\begin{tabular}{|c|c|c|c|c|c|c|c|c|c|c|c|c|c|c|c|}
\hline \multirow[b]{2}{*}{ State $^{\mathrm{a}}$} & \multicolumn{5}{|c|}{ Accident-Involvement Rates } & \multicolumn{5}{|c|}{ Accident-Fatality Rates } & \multicolumn{5}{|c|}{ Accident-Injury Rates } \\
\hline & FAI-U & FAI-R & FAI & FAP & FAS & FAI-U & FAI-R & FAI & FAP & FAS & FAl-U & FAI-R & FAI & FAP & FAS \\
\hline $\mathrm{AL}$ & 4.68 & 1.26 & 1.85 & 5.16 & 3.96 & 3.29 & 1.84 & 2.09 & 6.34 & 7.84 & 4.66 & 1.24 & 1.83 & 5.62 & 4.22 \\
\hline $\mathrm{AZ}$ & 2.71 & 1.60 & 1.76 & 2.12 & 1.45 & 3.56 & 2.13 & 2.33 & 4.97 & 1.20 & 2.89 & 1.65 & 1.82 & 2.20 & 2.77 \\
\hline $\mathrm{AR}$ & 4.82 & 1.73 & 2.09 & 4.69 & 6.84 & 6.61 & 2.28 & 2.78 & 8.88 & 7.10 & 4.09 & 1.95 & 2.20 & 4.38 & 5.94 \\
\hline $\mathrm{CA}$ & 1.92 & 1.64 & 1.76 & 1.15 & 2.22 & 1.39 & 2.56 & 2.06 & 1.98 & 3.81 & 1.82 & 1.68 & 1.74 & 1.12 & 2.67 \\
\hline $\mathrm{CO}$ & 6.28 & 2.76 & 3.60 & 4.11 & 4.42 & 3.38 & 2.45 & 2.67 & 6.58 & 5.83 & 5.47 & 2.82 & 3.45 & 3.95 & 3.67 \\
\hline CT & 2.67 & $4.60^{\mathrm{b}}$ & 3.23 & 2.56 & 9.09 & 1.01 & $5.11^{\mathrm{b}}$ & 2.20 & 1.17 & 9.09 & 1.71 & $4.61^{b}$ & 2.55 & 1.89 & 7.09 \\
\hline $\mathrm{DE}$ & 2.56 & - & 2.56 & 7.35 & 4.81 & 1.66 & - & 1.66 & $13.50^{\mathrm{b}}$ & 7.69 & 3.46 & - & 3.46 & 7.18 & 3.08 \\
\hline FL & 2.25 & 1.21 & 1.50 & 3.73 & 6.33 & 1.74 & 2.62 & 2.38 & 5.92 & 6.12 & 2.36 & 1.28 & 1.58 & 4.12 & 7.92 \\
\hline GA & 4.87 & 1.65 & 2.28 & 6.15 & 4.04 & 2.37 & 1.86 & 1.96 & 8.30 & 6.74 & 4.37 & 1.75 & 2.26 & 6.43 & 3.71 \\
\hline ID & 1.73 & 2.30 & 2.22 & 4.93 & 2.29 & 0 & 2.06 & 1.78 & 7.46 & 2.54 & 1.18 & 2.12 & 1.99 & 3.54 & 1.69 \\
\hline IL & $8.75^{b}$ & 1.76 & 3.53 & 6.40 & 1.78 & 5.33 & 1.39 & 2.38 & 7.84 & 2.30 & $8.23^{b}$ & 1.49 & 3.20 & 6.12 & 1.55 \\
\hline IN & 4.58 & 1.92 & 2.43 & 4.72 & 2.80 & 3.51 & 1.22 & 1.66 & 7.66 & 4.02 & 4.36 & 1.81 & 2.30 & 4.42 & 2.32 \\
\hline IA & 3.54 & 1.78 & 2.02 & 4.03 & 1.24 & 2.68 & 1.05 & 1.26 & 6.14 & 0.73 & 3.78 & 1.46 & 1.76 & 3.48 & 0.88 \\
\hline $\mathrm{KS}$ & 4.48 & 2.04 & 2.56 & 5.11 & 1.38 & 5.52 & 1.88 & 2.66 & 9.35 & 1.72 & 3.66 & 1.91 & 2.28 & 4.09 & 1.12 \\
\hline $\mathbf{K Y}$ & 5.13 & 1.46 & 1.99 & 5.74 & 8.30 & 3.22 & 1.50 & 1.75 & 6.60 & 6.25 & 5.52 & 1.33 & 1.94 & 5.28 & 8.12 \\
\hline LA & 3.54 & 1.30 & 1.88 & 3.53 & 2.39 & 4.90 & 1.77 & 2.59 & 5.73 & 3.28 & 4.57 & 1.32 & 2.16 & 4.46 & 2.85 \\
\hline $\mathrm{ME}$ & $9.03^{b}$ & 2.44 & 2.93 & 5.44 & 2.28 & 0 & 2.34 & 2.16 & 6.58 & 2.17 & 4.52 & 1.53 & 1.75 & 5.00 & 1.63 \\
\hline$M D$ & 3.08 & 3.95 & 3.46 & 3.56 & 12.40 & 1.62 & 4.03 & 2.69 & 3.66 & 8.99 & 3.41 & 3.98 & $3.66^{\mathrm{b}}$ & 4.32 & 13.40 \\
\hline MA & 1.42 & $6.47^{b}$ & 2.68 & 3.43 & $46.10^{b}$ & 1.30 & $6.23^{b}$ & 2.53 & 3.93 & $52.20^{b}$ & 1.13 & $4.99^{b}$ & 2.09 & 3.02 & $43.90^{\mathrm{b}}$ \\
\hline MI & 3.16 & 1.59 & 2.12 & 2.68 & 0.81 & 1.52 & 1.23 & 1.33 & 3.96 & 1.22 & 3.04 & 1.29 & 1.87 & 2.61 & 1.38 \\
\hline MN & 2.66 & 2.06 & 2.29 & 4.19 & 2.16 & 2.02 & 1.72 & 1.83 & 7.69 & 7.84 & 2.08 & 1.46 & 1.69 & 3.28 & 1.86 \\
\hline MS & 2.01 & 1.19 & 1.35 & 4.48 & 0.65 & 2.46 & 1.81 & 1.93 & 9.26 & 1.62 & 1.85 & 1.10 & 1.25 & 4.55 & 0.50 \\
\hline MO & 5.18 & 1.78 & 2.61 & 5.36 & 2.49 & 4.30 & 1.23 & 1.99 & 9.68 & 3.25 & 5.53 & 1.63 & 2.59 & 5.06 & 2.23 \\
\hline MT & $10.00^{b}$ & 2.52 & 2.89 & 5.38 & 1.02 & 3.12 & 1.44 & 1.52 & 7.97 & 2.04 & 4.69 & 1.79 & 1.93 & 3.95 & 0.20 \\
\hline NE & 6.97 & 1.77 & 2.09 & 3.62 & 0.99 & 6.58 & 1.10 & 1.43 & 5.75 & 0 & 6.58 & 1.17 & 1.50 & 3.54 & 0.54 \\
\hline NV & 6.33 & 1.57 & 1.97 & 4.35 & 3.17 & $8.89^{\mathrm{b}}$ & 1.14 & 1.79 & 10.50 & 7.94 & 5.67 & 1.58 & 1.93 & 3.72 & 2.54 \\
\hline NH & 0.22 & 1.39 & 1.18 & 4.36 & 3.33 & 0 & 1.49 & 1.22 & 5.77 & 5.56 & 0 & 1.14 & 0.94 & 4.17 & 2.22 \\
\hline NJ & 2.77 & $7.65^{b}$ & $4.24^{b}$ & 6.80 & 9.69 & 1.56 & $6.56^{\mathrm{b}}$ & 3.06 & 4.57 & 11.50 & 2.69 & $8.00^{b}$ & $4.28^{b}$ & 6.86 & 11.30 \\
\hline NM & $9.64^{b}$ & 1.92 & 2.35 & 4.77 & 12.20 & $9.01^{b}$ & 1.93 & 2.32 & 6.99 & 5.56 & $8.92^{\mathrm{b}}$ & 1.86 & 2.25 & 4.62 & 10.60 \\
\hline NY & 5.69 & 2.93 & $3.98^{\mathrm{b}}$ & 3.16 & 9.48 & 2.04 & 1.38 & 1.63 & 4.61 & 10.30 & 4.49 & 2.56 & 3.28 & 2.71 & 10.00 \\
\hline NC & 5.92 & 2.28 & 2.97 & 5.17 & 6.37 & 5.08 & 2.92 & $3.33^{b}$ & 6.71 & 11.00 & 6.37 & 2.19 & 2.99 & 5.53 & 6.22 \\
\hline $\mathrm{OH}$ & 3.16 & 2.27 & 2.52 & 4.42 & 11.00 & 1.41 & 1.32 & 1.35 & 6.07 & 9.88 & 2.85 & 2.02 & 2.25 & 4.40 & 1070 \\
\hline $\mathrm{OK}$ & 3.76 & 1.47 & 1.91 & 3.61 & 1.73 & 2.70 & 2.06 & 2.18 & 4.88 & 0.71 & 3.34 & 1.36 & 1.74 & 3.05 & 1.59 \\
\hline OR & 3.99 & 2.20 & 2.48 & 4.17 & 1.63 & 2.47 & 1.12 & 1.33 & 5.85 & 4.07 & 3.82 & 1.69 & 2.02 & 2.94 & 0.57 \\
\hline PA & 3.02 & 3.60 & 3.48 & 7.21 & 7.92 & 2.12 & 2.97 & 2.79 & 10.20 & 9.29 & 2.68 & 3.28 & 3.15 & 7.28 & 6.42 \\
\hline $\mathrm{RI}$ & 2.27 & 1.98 & 2.16 & 1.37 & 16.70 & 0.71 & 3.70 & 1.80 & 1.71 & $66.70^{b}$ & 3.12 & 2.35 & 2.84 & 0.86 & $23.30^{\mathrm{b}}$ \\
\hline SC & 3.13 & 1.83 & 1.99 & 6.27 & 2.27 & 2.88 & 2.57 & 2.61 & 8.61 & 3.95 & 2.65 & 2.20 & 2.26 & 6.96 & 2.27 \\
\hline SD & $8.57^{b}$ & 2.09 & 2.18 & 3.94 & 1.49 & $14.30^{b}$ & 0.42 & 0.62 & 5.38 & 2.13 & 5.71 & 1.38 & 1.95 & 2.94 & 0 \\
\hline TN & 7.97 & 1.48 & 2.48 & 5.56 & 6.26 & 5.59 & 1.63 & 2.24 & 6.97 & 12.10 & $7.70^{\mathrm{b}}$ & 1.44 & 2.41 & 5.85 & 4.67 \\
\hline
\end{tabular}


TABLE A.4 (Cont.)

\begin{tabular}{|c|c|c|c|c|c|c|c|c|c|c|c|c|c|c|c|}
\hline \multirow[b]{2}{*}{ State } & \multicolumn{5}{|c|}{ Accident-Involvement Rates } & \multicolumn{5}{|c|}{ Accident-Fatality Rates } & \multicolumn{5}{|c|}{ Accident-Injury Rates } \\
\hline & FAI-U & FAI-R & FAI & FAP & FAS & FAI-U & FAl-R & FAl & FAP & FAS & FAI-U & FAI-R & FAl & FAP & FAS \\
\hline $\mathrm{TX}$ & 2.74 & 1.56 & 2.00 & 2.78 & 1.09 & 1.93 & 1.97 & 1.95 & 4.77 & 1.84 & 2.53 & 1.42 & 1.83 & 2.53 & 0.92 \\
\hline V'T & 0 & 1.38 & 1.33 & 6.30 & 6.80 & 0 & 0.43 & 0.42 & 3.36 & 24.00 & 0 & 1.08 & 1.04 & 6.13 & 4.40 \\
\hline VA & 2.63 & 2.54 & 2.56 & 4.67 & 5.03 & 1.91 & 1.76 & 1.80 & 7.28 & 7.73 & 2.49 & 2.46 & 2.47 & 5.39 & 4.81 \\
\hline WA & 1.61 & 2.50 & 2.10 & 2.62 & 0.73 & 0.80 & 1.47 & 1.17 & 2.54 & 0 & 1.49 & 2.14 & 1.85 & 2.11 & 0.51 \\
\hline wV & 2.95 & 3.10 & 3.07 & $11.70^{\mathrm{b}}$ & 7.87 & 1.28 & 1.67 & 1.60 & $17.80^{\mathrm{b}}$ & 1.70 & 2.78 & 2.80 & 2.79 & $9.91^{b}$ & 7.13 \\
\hline WI & 5.29 & 1.74 & 2.18 & 2.80 & 3.24 & 0.77 & 0.66 & 0.67 & 3.62 & 3.68 & 4.33 & 1.45 & 1.81 & 2.51 & 3.16 \\
\hline WY & 2.98 & 3.42 & 3.40 & 3.41 & 3.70 & 0 & 2.08 & 2.01 & 6.22 & 3.70 & 0 & 2.84 & 2.74 & 1.86 & 2.35 \\
\hline USA & 3.58 & 2.03 & 2.44 & 3.94 & 3.48 & 2.37 & 1.91 & 2.03 & 5.82 & 4.62 & 3.36 & 1.89 & 2.28 & 3.82 & 3.30 \\
\hline$a^{c}$ & 2.36 & 1.25 & 0.69 & 1.77 & 6.98 & 2.70 & 1.27 & 0.63 & 3.01 & 11.74 & 1.99 & 1.22 & 0.69 & 1.79 & 7.10 \\
\hline
\end{tabular}

a Includes only the 48 contiguous states, plus the totals for the nation as a whole (USA).

b Rates are two or more standard deviations greater than the national average rate for that highway category.

c $\sigma=$ standard deviation. 
TABLE A.5a Total and Mainline-Only, Reportable Railroad-Freight-Car Accidents on Carrier-Owned Track and Estimated Car-Kilometers for 1986,1987 , and $1988\left(10^{-8}\right.$ accidents per railcar-kilometer)

\begin{tabular}{|c|c|c|c|c|c|c|c|c|c|}
\hline \multirow[b]{3}{*}{ State $^{\mathbf{a}}$} & \multicolumn{6}{|c|}{ Accidents Involving Railcars } & & & \\
\hline & \multicolumn{2}{|c|}{1986} & \multicolumn{2}{|c|}{1987} & \multicolumn{2}{|c|}{1988} & \multicolumn{3}{|c|}{ Estimated Car-Kilometers } \\
\hline & Total & $\begin{array}{l}\text { Main } \\
\text { Only }\end{array}$ & Total & $\begin{array}{c}\text { Main } \\
\text { Only }\end{array}$ & Total & $\begin{array}{l}\text { Main } \\
\text { Only }\end{array}$ & 1986 & 1987 & 1988 \\
\hline $\mathrm{AL}$ & 33 & 17 & 47 & 33 & 41 & 25 & $851,331,810$ & $979,823,840$ & $992,034,050$ \\
\hline$\overline{A Z}$ & 24 & 18 & 24 & 20 & 27 & 22 & $1,715,650,560$ & $1,847,785,910$ & $1,870,812,350$ \\
\hline AR & 37 & 19 & 35 & 19 & 72 & 34 & $733,103,630$ & $820,528,890$ & $863,655,180$ \\
\hline $\mathrm{CA}$ & 116 & 60 & 80 & 48 & 105 & 56 & $2,273,667,000$ & $2,424,771,810$ & $2,430,681,630$ \\
\hline $\mathrm{CO}$ & 20 & 14 & 13 & 6 & 39 & 23 & $1,387,248,800$ & $1,508,739,380$ & $1,527,540,740$ \\
\hline CT & 3 & 2 & 2 & 1 & 3 & 0 & $11,332,830$ & $11,996,330$ & $12,025,570$ \\
\hline $\mathrm{DE}$ & 3 & 1 & 3 & 2 & 2 & 2 & $10,933,250$ & $11,890,750$ & $11,085,350$ \\
\hline DC & 0 & 0 & 2 & 2 & 0 & 0 & 600,000 & 633,540 & 692,240 \\
\hline FL & 23 & 17 & 37 & 18 & 42 & 24 & $803,177,770$ & $949,844,130$ & $1,009,288,710$ \\
\hline GA & 71 & 34 & 82 & 34 & 78 & 34 & $1,102,592,500$ & $1,210,796,110$ & $1,262,297,020$ \\
\hline ID & 18 & 16 & 23 & 14 & 34 & 15 & $304,937,430$ & $341,302,320$ & $376,347,580$ \\
\hline IL & 294 & 78 & 270 & 84 & 271 & 73 & $2,513,780,400$ & $2,707,385,820$ & $2,985,382,880$ \\
\hline IN & 61 & 27 & 60 & 24 & 66 & 25 & $1,458,766,000$ & $1,617,326,020$ & $1,734,756,630$ \\
\hline IA & 111 & 45 & 88 & 46 & 87 & 51 & $629,783,060$ & $691,587,220$ & $727,936,440$ \\
\hline $\mathrm{KS}$ & 65 & 35 & 69 & 36 & 101 & 49 & $2,157,920,900$ & $2,324,118,870$ & $2,469,570,360$ \\
\hline $\mathbf{K Y}$ & 50 & 25 & 40 & 21 & 39 & 20 & $1,046,253,600$ & $1,060,549,250$ & $1,084,396,770$ \\
\hline LA & 53 & 25 & 35 & 10 & 61 & 20 & $418,348,180$ & $494,741,740$ & $510,825,980$ \\
\hline ME & 10 & 6 & 11 & 5 & 14 & 7 & $35,434,970$ & $37,415,770$ & $26,629,940$ \\
\hline MD & 24 & 14 & 25 & 11 & 22 & 6 & $395,153,790$ & $450,622,170$ & $483,340,880$ \\
\hline MA & 21 & 10 & 19 & 7 & 13 & 5 & $170,282,690$ & $188,791,500$ & $177,896,540$ \\
\hline MI & 74 & 33 & 65 & 19 & 75 & 36 & $403,518,040$ & $430,335,300$ & $483,150,240$ \\
\hline $\mathrm{MN}$ & 111 & 34 & 89 & 47 & 119 & 55 & $1,285,943,200$ & $1,425,718,310$ & $1,514,944,760$ \\
\hline MS & 46 & 34 & 46 & 35 & 32 & 27 & $303,436,290$ & $355,642,080$ & $377,899,410$ \\
\hline MO & 93 & 43 & 81 & 42 & 116 & 66 & $2,027,705,300$ & $2,248,105,970$ & $2,298,656,900$ \\
\hline MT & 28 & 21 & 29 & 19 & 52 & 29 & $2,075,546,200$ & $2,344,978,290$ & $2,468,228,300$ \\
\hline $\mathrm{NE}$ & 65 & 34 & 85 & 44 & 86 & 43 & $1,608,549,600$ & $1,766,405,630$ & $1,930,074,800$ \\
\hline NV & 7 & 4 & 3 & 2 & 9 & 6 & $214,382,250$ & $233,157,130$ & $226,713,630$ \\
\hline $\mathrm{NH}$ & 1 & 1 & 3 & 2 & 3 & 2 & $15,160,130$ & $17,128,110$ & $12,362,290$ \\
\hline NJ & 21 & 4 & 16 & 9 & 17 & 8 & $151,474,220$ & $169,538,070$ & $168,251,770$ \\
\hline NM & 19 & 11 & 21 & 17 & 20 & 15 & $2,101,734,500$ & $2,263,605,120$ & $2,314,504,570$ \\
\hline NY & 48 & 26 & 51 & 31 & 54 & 25 & $663,533,870$ & $749,668,940$ & $743,981,120$ \\
\hline
\end{tabular}


TABLE A.5a (Cont.)

\begin{tabular}{|c|c|c|c|c|c|c|c|c|c|}
\hline \multirow[b]{3}{*}{ State $^{\mathbf{a}}$} & \multicolumn{6}{|c|}{ Accidents Involving Railcars } & & & \\
\hline & \multicolumn{2}{|c|}{1986} & \multicolumn{2}{|c|}{1987} & \multicolumn{2}{|c|}{1988} & \multicolumn{3}{|c|}{ Estimated Car-Kilometers } \\
\hline & Total & $\begin{array}{l}\text { Main } \\
\text { Only }\end{array}$ & Total & $\begin{array}{l}\text { Main } \\
\text { Only }\end{array}$ & Total & $\begin{array}{c}\text { Main } \\
\text { Only }\end{array}$ & 1986 & 1987 & 1988 \\
\hline $\mathrm{NC}$ & 24 & 12 & 27 & 8 & 32 & 15 & $444,693,450$ & $493,029,240$ & $509,057,810$ \\
\hline ND & 25 & 17 & 30 & 23 & 20 & 15 & $1,148,575,200$ & $1,237,035,750$ & $1,339,254,790$ \\
\hline $\mathrm{OH}$ & 111 & 52 & 81 & 36 & 97 & 46 & $2,076,285,600$ & $2,280,043,190$ & $2,399,880,270$ \\
\hline OK & 47 & 27 & 37 & 20 & 46 & 23 & $895,916,570$ & $1,050,057,770$ & $1,221,035,760$ \\
\hline OR & 45 & 19 & 52 & 26 & 61 & 27 & $383,348,650$ & $425,016,590$ & $447,355,090$ \\
\hline PA & 82 & 63 & 82 & 46 & 71 & 39 & $1,687,160,600$ & $1,941,804,780$ & $2,004,933,600$ \\
\hline RI & 0 & 0 & 0 & 0 & 0 & 0 & 233,600 & 266,390 & 226,980 \\
\hline SC & 15 & 7 & 17 & 13 & 19 & 14 & $323,618,890$ & $358,794,520$ & $377,652,450$ \\
\hline $\mathrm{SD}$ & 13 & 10 & 31 & 30 & 16 & 14 & $159,386,240$ & $207,003,930$ & $219,958,960$ \\
\hline $\mathrm{TN}$ & 49 & 17 & 52 & 21 & 86 & 23 & $1,003,857,150$ & $1,112,971,030$ & $1,137,997,310$ \\
\hline $\mathrm{TX}$ & 232 & 111 & 201 & 95 & 239 & 99 & $3,298,802,300$ & $3,796,692,540$ & $4,034,302,850$ \\
\hline UT & 11 & 4 & 6 & 3 & 36 & 13 & $298,087,350$ & $324,192,840$ & $321,733,150$ \\
\hline $\mathrm{VT}$ & 2 & 1 & 3 & 2 & 8 & 6 & $33,466,640$ & $38,164,410$ & $32,901,380$ \\
\hline VA & 51 & 17 & 57 & 30 & 64 & 30 & $1,194,261,760$ & $1,298,851,180$ & $1,393,158,010$ \\
\hline WA & 29 & 11 & 25 & 14 & 35 & 11 & $794,255,400$ & $930,905,930$ & $979,833,540$ \\
\hline WV & 66 & 53 & 58 & 45 & 39 & 30 & $574,169,340$ & $582,014,590$ & $641,776,430$ \\
\hline WI & 85 & 34 & 80 & 37 & 68 & 39 & $452,410,380$ & $477,699,960$ & $541,116,590$ \\
\hline WY & 28 & 15 & 32 & 18 & 39 & 19 & $1,097,080,200$ & $1,227,910,990$ & $1,353,994,100$ \\
\hline USA & 2465 & 1178 & 2325 & 1165 & 2675 & 1266 & $44,736,892,090$ & $49,467,359,950$ & $52,052,133,700$ \\
\hline
\end{tabular}

a Includes the 48 contiguous states, the District of Columbia, and the totals for the United States (USA). 
TABLE A.5b Railroad-Freight-Car Accident Rates, by State, for 1986, 1987, 1988, and $1985-1988$ Combined $\left(10^{-8}\right.$ accidents per railcar-kilometer $\left.{ }^{\mathrm{a}}\right)$

\begin{tabular}{|c|c|c|c|c|c|c|c|c|}
\hline \multirow[b]{2}{*}{ State $^{b}$} & \multicolumn{2}{|c|}{1986} & \multicolumn{2}{|c|}{1987} & \multicolumn{2}{|c|}{1988} & \multicolumn{2}{|c|}{$1985-88$} \\
\hline & Total & $\begin{array}{l}\text { Main } \\
\text { Only }\end{array}$ & Total & $\begin{array}{c}\text { Main } \\
\text { Only }\end{array}$ & Total & $\begin{array}{c}\text { Main } \\
\text { Only }\end{array}$ & Total & $\begin{array}{c}\text { Main } \\
\text { Only }\end{array}$ \\
\hline $\mathrm{AL}$ & 3.88 & 2.00 & 4.80 & 3.37 & 4.13 & 2.52 & 4.80 & 2.75 \\
\hline $\mathrm{AZ}$ & 1.40 & 1.05 & 1.30 & 1.08 & 1.44 & 1.18 & 1.75 & 1.30 \\
\hline $\mathrm{AR}$ & 5.05 & 2.59 & 4.27 & 2.32 & 8.34 & 3.94 & 6.78 & 3.54 \\
\hline $\mathrm{CA}$ & 5.10 & 2.64 & 3.30 & 1.98 & 4.32 & 2.30 & 5.10 & 2.51 \\
\hline $\mathrm{CO}$ & 1.44 & 1.01 & 0.86 & 0.40 & 2.55 & 1.51 & 1.73 & 1.02 \\
\hline $\mathrm{CT}$ & 26.47 & 17.65 & 16.67 & 8.34 & 24.95 & 0 & $28.27^{c}$ & 10.10 \\
\hline $\mathrm{DE}$ & 27.44 & 9.15 & 25.23 & 16.82 & 18.04 & 18.04 & 17.71 & 11.07 \\
\hline DC & 0 & 0 & 316 & 316 & 0 & 0 & $117.09^{\mathrm{c}}$ & $78.06^{c}$ \\
\hline FL & 2.86 & 2.12 & 3.90 & 1.90 & 4.16 & 2.38 & 4.02 & 2.21 \\
\hline GA & 6.44 & 3.08 & 6.77 & 2.81 & 6.18 & 2.69 & 6.44 & 2.84 \\
\hline ID & 5.90 & 5.25 & 6.74 & 4.10 & 9.03 & 3.99 & 7.01 & 4.14 \\
\hline IL & 11.70 & 3.10 & 9.97 & 3.10 & 9.08 & 2.45 & 10.67 & 2.97 \\
\hline IN & 4.18 & 1.85 & 3.71 & 1.48 & 3.80 & 1.44 & 4.64 & 1.93 \\
\hline IA & 17.63 & 7.15 & 12.72 & 6.65 & 11.95 & 7.01 & 14.67 & 7.16 \\
\hline $\mathrm{KS}$ & 3.01 & 1.62 & 2.97 & 1.55 & 4.09 & 1.98 & 3.61 & 1.75 \\
\hline $\mathrm{KY}$ & 4.78 & $2.3 \varrho$ & 3.77 & 1.98 & 3.60 & 1.84 & 4.48 & 2.44 \\
\hline LA & 12.67 & 5.98 & 7.07 & 2.02 & 11.94 & 3.92 & 12.37 & 4.28 \\
\hline $\mathrm{ME}$ & 28.22 & 16.93 & 29.40 & 13.36 & 52.57 & 26.29 & $37.80^{\mathrm{c}}$ & $18.53^{c}$ \\
\hline MD & 6.07 & 3.54 & 5.55 & 2.44 & 4.55 & 1.24 & 5.62 & 2.58 \\
\hline MA & 12.33 & 5.87 & 10.06 & 3.71 & 7.31 & 2.81 & 11.65 & 4.97 \\
\hline MI & 18.34 & 8.18 & 15.10 & 4.42 & 15.52 & 7.45 & 16.47 & 7.19 \\
\hline $\mathrm{MN}$ & 8.63 & 2.64 & 6.24 & 3.30 & 7.86 & 3.63 & 8.48 & 3.16 \\
\hline MS & 15.16 & 11.20 & 12.93 & 9.84 & 8.47 & 7.14 & 11.52 & 8.51 \\
\hline MO & 4.59 & 2.12 & 3.60 & 1.87 & 5.05 & 2.87 & 5.28 & 2.56 \\
\hline MT & 1.35 & 1.01 & 1.24 & 0.81 & 2.11 & 1.17 & 1.73 & 1.10 \\
\hline NE & 4.04 & 2.11 & 4.81 & 2.49 & 4.46 & 2.23 & 4.63 & 2.56 \\
\hline NV & 3.27 & 1.87 & 1.29 & 0.86 & 3.97 & 2.65 & 3.23 & 2.19 \\
\hline $\mathrm{NH}$ & 6.60 & 6.60 & 17.52 & 11.68 & 24.27 & 16.18 & 21.45 & $17.16^{\mathrm{c}}$ \\
\hline $\mathrm{NJ}$ & 13.86 & 2.64 & 9.44 & 5.31 & 10.10 & 4.75 & 12.38 & 4.82 \\
\hline NM & 0.90 & 0.52 & 0.93 & 0.75 & 0.86 & 0.65 & 0.94 & 0.66 \\
\hline NY & 7.23 & 3.92 & 6.80 & 4.14 & 7.26 & 3.36 & 8.32 & 4.30 \\
\hline $\mathrm{NC}$ & 5.40 & 2.70 & 5.48 & 1.62 & 6.29 & 2.95 & 5.70 & 2.27 \\
\hline ND & 2.18 & 1.48 & 2.43 & 1.86 & 1.49 & 1.12 & 2.41 & 1.80 \\
\hline $\mathrm{OH}$ & 5.35 & 2.50 & 3.55 & 1.58 & 4.04 & 1.92 & 4.73 & 2.12 \\
\hline OK & 5.25 & 3.01 & 3.52 & 1.90 & 3.77 & 1.88 & 4.66 & 2.72 \\
\hline OR & 11.74 & 4.96 & 12.23 & 6.12 & 13.64 & 6.04 & 12.48 & 5.77 \\
\hline PA & 4.86 & 3.73 & 4.22 & 2.37 & 3.54 & 1.95 & 4.38 & 2.69 \\
\hline $\mathrm{RI}$ & 0 & 0 & 0 & 0 & 0 & 0 & $105.33^{c}$ & 0 \\
\hline SC & 4.64 & 2.16 & 4.74 & 3.62 & 5.03 & 3.71 & 5.11 & 3.31 \\
\hline SD & 8.16 & 6.27 & 14.98 & 14.49 & 7.27 & 6.36 & 10.19 & 9.09 \\
\hline $\mathrm{TN}$ & 4.88 & 1.69 & 4.67 & 1.89 & 7.56 & 2.02 & 5.59 & 1.88 \\
\hline $\mathrm{TX}$ & 7.03 & 3.36 & 5.29 & 2.50 & 5.92 & 2.45 & 7.12 & 3.16 \\
\hline UT & 3.69 & 1.34 & 1.85 & 0.93 & 11.19 & 4.04 & 5.78 & 2.31 \\
\hline VT & 5.98 & 2.99 & 7.86 & 5.24 & 24.32 & 18.24 & 15.22 & 11.59 \\
\hline VA & 4.27 & 1.42 & 4.39 & 2.31 & 4.59 & 2.15 & 4.35 & 1.91 \\
\hline
\end{tabular}


TABLE A.5b (Cont.)

\begin{tabular}{|c|c|c|c|c|c|c|c|c|}
\hline \multirow[b]{2}{*}{ State $^{b}$} & \multicolumn{2}{|c|}{1986} & \multicolumn{2}{|c|}{1987} & \multicolumn{2}{|c|}{1988} & \multicolumn{2}{|c|}{$1985-88$} \\
\hline & Total & $\begin{array}{l}\text { Main } \\
\text { Only }\end{array}$ & Total & $\begin{array}{l}\text { Main } \\
\text { Only }\end{array}$ & Total & $\begin{array}{l}\text { Main } \\
\text { Only }\end{array}$ & Total & $\begin{array}{l}\text { Main } \\
\text { Only } \\
\end{array}$ \\
\hline WA & 3.65 & 1.38 & 2.69 & 1.50 & 3.57 & 1.12 & 3.49 & 1.44 \\
\hline wV & 11.49 & 9.23 & 9.97 & 7.73 & 6.08 & 4.67 & 9.61 & 7.42 \\
\hline WI & 18.79 & 7.52 & 16.75 & 7.75 & 12.57 & 7.21 & 16.53 & 7.66 \\
\hline WY & 2.55 & 1.37 & 2.61 & 1.47 & 2.88 & 1.40 & 3.10 & 1.97 \\
\hline USA & 5.51 & 2.63 & 4.70 & 2.36 & 5.14 & 2.43 & 5.57 & 2.66 \\
\hline$\sigma^{d}$ & - & - & - & - & - & - & 21.48 & 11.12 \\
\hline
\end{tabular}

a Nationwide average fatality rate, using count of fatalities consistent with combination-truck fatality counts, is $6.50 \times 10^{-10}$ fatalities per railcar-kilometer. Nationwide average injury rate, using count of injuries censistent with combination-truck injury counts, is $7.83 \times 10^{-8}$ injuries per railcarkilometer.

b Includes the 48 contiguous states, the District of Columbia, and the totals for the United States (USA).

c Rates are one or more standard deviations greater than the national average rate for that category (i.e., all accidents on carrier-owned track or accidents on mainlines only).

d $\mathbf{o}=$ standard deviation. 
TABLE A.6 Freight-Vessel Accident and Casualty-Involvement Rates on the Domestic Waterways of the United States, Including Coastwise Shipping, for $1985\left(10^{-6}\right.$ involvements per shipment-kilometer $\left.{ }^{\mathrm{a}}\right)$

\begin{tabular}{lccccc}
\hline \multicolumn{1}{c}{ Waterway System } & $\begin{array}{c}\text { Total Accident } \\
\text { Count }\end{array}$ & $\begin{array}{c}\text { Total Accident } \\
\text { Involvements }\end{array}$ & $\begin{array}{c}\text { Total Vessel c } \\
\text { Casualty Count }\end{array}$ & $\begin{array}{c}\text { Involvement } \\
\text { Rate }\end{array}$ & $\begin{array}{c}\text { Casualty } \\
\text { Rate }\end{array}$ \\
\hline Atlantic Coast & 237 & 410 & 371 & 5.14 & 4.65 \\
Gulf Coast & 202 & 518 & 454 & 4.41 & 3.87 \\
Pacific Coast & 64 & 105 & 88 & 1.64 & 1.37 \\
Mississippi (incl. Arkansas, & 480 & 3833 & 2170 & 5.30 & 3.00 \\
Ohio, Tennessee-Tombigbee, & & & & & \\
$\quad$ and Missouri systems) & 77 & 151 & 129 & 0.62 & 0.53 \\
Great Lakes & 1060 & 5017 & 3212 & 4.08 & 2.62 \\
All Inland Waterways & 134 & 253 & 206 & 0.13 & 0.10 \\
Coastwise Movements & & & & & \\
\hline
\end{tabular}

a Shipment weight for spent fuel cask on barge estimated at 500 short tons, on the basis of Tobin, R.L.,

N.K. Meshkov, and R.H. Jones, Preliminary Assessment of the Costs and Risks of Transporting Spent Fuel by Barges, Argonne National Laboratory Report ANL/ER-TM-85-2 (Dec.1985).

b Vessel was involved in accident only; no damage reported.

c Vessel was involved in accident and sustaine casualty by reportable damage, fatality, or injury. 
TABLE A.7 Freight-Vessel Accident and Casualty-Involvement Rates on the Domestic Waterways of the United States, Including Coastwise Shipping, for $1986\left(10^{-6}\right.$ involvements per shipment-kilometer $\left.^{\text {a }}\right)$

\begin{tabular}{lccccc}
\hline \multicolumn{1}{c}{ Waterway System } & $\begin{array}{c}\text { Total Accident } \\
\text { Count }\end{array}$ & $\begin{array}{c}\text { Total Accident } \\
\text { Involvements }\end{array}$ & $\begin{array}{c}\text { Total Vessel } \\
\text { Casualty Count }\end{array}$ & $\begin{array}{c}\text { Involvement } \\
\text { Rate }\end{array}$ & $\begin{array}{c}\text { Casualty } \\
\text { Rate }\end{array}$ \\
\hline Atlantic Coast & 237 & 488 & 384 & 5.91 & 4.65 \\
Gulf Coast & 236 & 701 & 618 & 5.59 & 4.93 \\
Pacific Coast & 90 & 164 & 135 & 2.45 & 2.02 \\
Mississippi (incl. Arkansas, & 347 & 2950 & 1520 & 3.83 & 1.97 \\
$\quad$ Ohio, Tennessee-Tombigbee, & & & & & \\
and Missouri systems) & 76 & 144 & 112 & 0.66 & 0.51 \\
Great Lakes & 986 & 4447 & 2769 & 3.52 & 2.19 \\
All Inland Waterways & 137 & 264 & 208 & 0.14 & 0.11 \\
Coastwise Movements & & & & & \\
\hline
\end{tabular}

a Shipment weight for spent fuel cask on barge estimated at 500 short tons, on the basis of Tobin, R.L.,

N.K. Meshkov, and R.H. Jones, Preliminary Assessment of the Costs and Risks of Transporting Spent Fuel by Barges, Argonne National Laboratory Report ANL/ER-TM-85-2 (Dec. 1985).

b Vessel was involved in accident only; no damage reported.

c Vessel was involved in accident and sustained casualty by reportable damage, fatality, or injury. 
TABLE A.8 Freight-Vessel Accident and Casualty-Involvement Rates on the Domestic Waterways of the United States, Including Coastwise Shipping, for $1987\left(10^{-6}\right.$ involvements per shipment-kilometer $\left.{ }^{a}\right)$

\begin{tabular}{|c|c|c|c|c|c|}
\hline Waterway System & $\begin{array}{c}\text { Total Accident } \\
\text { Count }\end{array}$ & $\begin{array}{l}\text { Total Accident } \\
\text { Involvements }^{b}\end{array}$ & $\begin{array}{c}\text { Total Vessel } \\
\text { Casualty Count }\end{array}$ & $\begin{array}{c}\text { Involvement } \\
\text { Rate }\end{array}$ & $\begin{array}{c}\text { Casualty } \\
\text { Rate }\end{array}$ \\
\hline Atlantic Coast & 181 & 363 & 316 & 4.36 & 3.80 \\
\hline Gulf Coast & 265 & 674 & 604 & 5.53 & 4.95 \\
\hline Pacific Coast & 69 & 104 & 88 & 1.41 & 1.20 \\
\hline $\begin{array}{l}\text { Mississippi (incl. Arkansas, } \\
\text { Ohio, Tennessee-Tombigbee, } \\
\text { and Missouri systems) }\end{array}$ & 411 & 3760 & 1898 & 4.64 & 2.34 \\
\hline Great Lakes & 87 & 174 & 120 & 0.75 & 0.51 \\
\hline All Inland Waterways & 1013 & 5075 & 3026 & 3.84 & 2.29 \\
\hline Coastwise Movements & 100 & 185 & 152 & 0.10 & 0.08 \\
\hline
\end{tabular}

a Shipment weight for spent fuel cask on barge estimated at 500 short tons, on the basis of Tobin, R.L., N.K. Meshkov, and R.H. Jones, Preliminary Assessment of the Costs and Risks of Transporting Spent Fuel by Barges, Argonne National Laboratory Report ANL/ER-TM-85-2 (Dec. 1985).

b Vessel was involved in accident only; no damage reported.

c Vessel was involved in accident and sustained casualty by reportable damage, fatality, or injury. 
TABLE A.9 Freight-Vessel Accident and Casualty-Involvement Rates on the Domestic Waterways of the United States, Including Coastwise Shipping, for $1988\left(10^{-6}\right.$ involvements per shipment-kilometer $\left.{ }^{a}\right)$

\begin{tabular}{lccccc}
\hline \multicolumn{1}{c}{ Waterway System } & $\begin{array}{c}\text { Total Accident } \\
\text { Count }\end{array}$ & $\begin{array}{c}\text { Total Accident } \\
\text { Involvements }\end{array}$ & $\begin{array}{c}\text { Total Vessel } \\
\text { Casualty Count }\end{array}$ & $\begin{array}{c}\text { Involvement } \\
\text { Rate }\end{array}$ & $\begin{array}{c}\text { Casualty } \\
\text { Rate }\end{array}$ \\
\hline Atlantic Coast & 258 & 573 & 410 & 6.33 & 4.53 \\
Gulf Coast & 286 & 824 & 685 & 5.74 & 4.77 \\
Pacific Coast & 62 & 110 & 95 & 1.39 & 1.20 \\
Mississippi (incl. Arkansas, & 568 & 3750 & 1990 & 4.52 & 2.40 \\
$\quad$ Ohio, Tennessee-Tombigbee, & & & & & \\
and Missouri systems) & 82 & 172 & 116 & 0.64 & 0.43 \\
Great Lakes & 1256 & 5429 & 3296 & 3.85 & 2.34 \\
All Inland Waterways & 200 & 367 & 331 & 0.20 & 0.18 \\
Coastwise Movements & & & & & \\
\hline
\end{tabular}

a Shipment weight for spent fuel cask on barge estimated at 500 short tons, on the basis of Tobin, R.L., N.K. Meshkov, and R.H. Jones, Preliminary Assessment of the Costs and Risks of Transporting Spent Fuel by Barges, Argonne National Laboratory Report ANL/ER-TM-85-2 (Dec. 1985).

b Vessel was involved in accident only; no damage reported.

c Vessel was involved in accident and sustained casualty by reportable damage, fatality, or injury. 
TABLE A.10 Freight-Vessel Accident and Casualty-Involvement Rates on the Domestic Waterways of the United States, Including Coastwise Shipping, for $1985-1988\left(10^{-6} \text { involvements per shipment-kilometer }^{\mathrm{a}}\right)^{\mathrm{b}}$

\begin{tabular}{|c|c|c|c|c|c|}
\hline Waterway System & $\begin{array}{c}\text { Total Accident } \\
\text { Count }\end{array}$ & $\begin{array}{l}\text { Total Accident } \\
\text { Involvements }\end{array}$ & $\begin{array}{c}\text { Total Vessel } \\
\text { Casualty Count }^{\mathrm{d}}\end{array}$ & $\begin{array}{l}\text { Involvement } \\
\text { Rate }\end{array}$ & $\begin{array}{c}\text { Casualty } \\
\text { Rate }\end{array}$ \\
\hline Atlantic Coast & 913 & 1834 & 1481 & 5.455 & $4.405^{\mathrm{e}}$ \\
\hline Gulf Coast & 988 & 2716 & 2360 & 5.341 & $4.641^{\mathrm{e}}$ \\
\hline Pacific Coast & 285 & 483 & 406 & 1.704 & 1.433 \\
\hline $\begin{array}{l}\text { Mississippi (incl. Arkansas, } \\
\text { Ohio, Tennessee-Tombigbee, } \\
\text { and Missouri systems) }\end{array}$ & 1806 & 14293 & 7878 & 4.563 & 2.419 \\
\hline Great Lakes & 322 & 641 & 477 & 0.666 & 0.495 \\
\hline All Inland Waterways & 4314 & 19967 & 12302 & 3.823 & 2.355 \\
\hline Coastwise Movements & 571 & 1069 & 897 & 0.142 & 0.119 \\
\hline
\end{tabular}

a Shipment weight for spent fuel cask on barge estimated at 500 short tons, on the basis of Tobin, R.L., N.K. Meshkov, and R.H. Jones, Preliminary Assessment of the Costs and Risks of Transporting Spent Fuel by Barges, Argonne National Laboratory Report ANL/ER-TM-85-2 (Dec. 1985).

b Composite fatality rate for inland waterway movements is $0.73 \times 10^{-8}$ per shipment-kilometer; fatality rate for all domestic water traffic (incl. coastwise) is $0.32 \times 10^{-8}$ per shipment-kilometer; composite injury rate for inland waterway movements is $2.05 \times 10^{-8}$ per shipment-kilometer; and injury rate for all domestic water traffic (incl. coastwise) is $0.90 \times 10^{-8}$ per shipment-kilometer.

c Vessel was involved in accident only; no damage reported.

d Vessel was involved in accident and sustained casualty by reportable damage, fatality, or injury.

e Values are more than one standard deviation greater than the 1985-88 national inland waterway average. 

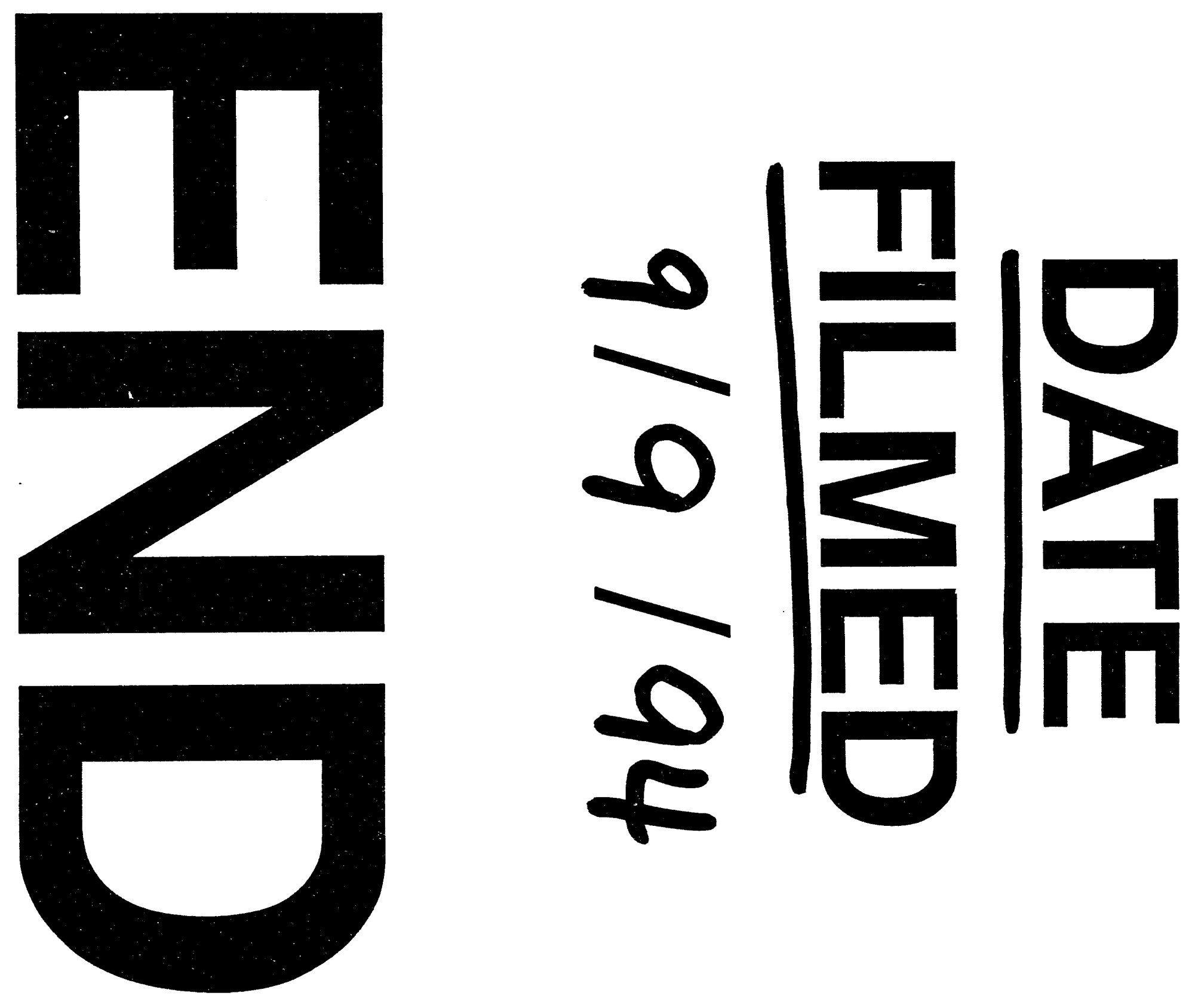
